\title{
The effect of surface lithology on arsenic and other heavy metals in surface water and groundwater in Mustang Valley, Nepal Himalaya
}

\author{
Steven H. Emerman ${ }^{1, *}$, Janae R. Nelson ${ }^{1}$, J. Kade Carlson ${ }^{1}$, Tracy K. Anderson ${ }^{1}$, \\ Anusha Sharma ${ }^{2}$ and Basanta R. Adhikari ${ }^{3}$ \\ ${ }^{1}$ Department of Earth Science, Utah Valley University, Orem, Utah 84058, USA \\ ${ }^{2}$ Department of Geology, Tri-Chandra Campus, Tribhuvan University, Kathmandu, Nepal \\ ${ }^{3}$ Department of Civil Engineering, Institute of Engineering, Tribhuvan University, Kathmandu, Nepal \\ *Corresponding author: StevenE@uvu.edu
}

\begin{abstract}
Recent studies have shown that elevated groundwater As occurs even in Kathmandu and Pokhara Valleys in Nepal, two tectonic valleys well upstream of the floodplain of the Ganges River. Moreover, studies in both valleys showed surface water As to be statistically indistinguishable from groundwater As, which led to the fluvial recharge model in which elevated groundwater As results from losing streams with elevated As, which is a consequence of rapid erosion caused by a combination of monsoon climate, tectonic uplift and deforestation. The objective of this study was to further test the fluvial recharge model in Mustang Valley, the third major tectonic valley in Nepal Himalaya far upstream from the floodplain of the Ganges River. In May 2011 water samples were collected from 33 surface water sites $(24$ directly from streams and 9 from canals, pipes or taps fed by streams) and 24 groundwater sites (10 directly from springs and 14 from pipes or taps fed by springs). The WHO As Standard was exceeded in $47 \%$ of surface water samples and $79 \%$ of groundwater samples, including all nine functioning water taps in Lo-Manthang, the largest village. Separating samples into a highAs Region I (geometric mean As $=0.071 \mathrm{mg} / \mathrm{L}$ ) and a low-As Region II (undetectable As for $85 \%$ of samples) showed that surface water As and groundwater As were statistically indistinguishable within each region. Only Region I receives overland flow from the exposed Mustang and Mugu Granites. The correspondence between groundwater As and watershed surface lithology is further evidence for the fluvial recharge model.
\end{abstract}

Key words: arsenic, deforestation, granite, Mustang, Nepal

Received: June 16, 2013

Revision accepted: May 2, 2014

\section{INTRODUCTION}

The widespread contamination of groundwater with arsenic (As) in the floodplain of the Ganges River in Bangladesh and West Bengal (India) has been well-documented over the past 15 years (Bhattacharaya et al. 1997; Dhar et al. 1997; Nickson et al. 1998). Studies over the past ten years have documented that the region of As contamination extends even into the Terai Zone, the Indo-Gangetic Plain of southern Nepal (Fig. 1) (Neku and Tandukar 2002; Bhattacharya et al. 2003; Shrestha et al. 2003; Brikowski et al. 2004, 2006; Emerman 2004; ENPHO and USGS 2004; Kanel et al. 2005; Tandukar et al. 2005; Neku et al. 2006; Panthi et al. 2006; Neku and Brikowski 2009; Pokhrel et al. 2009; Emerman et al. 2012). According to the most recent count in a scholarly journal, 737,009 groundwater samples in Nepal have been tested for As, of which $7.9 \%$ exceeded the WHO (World Health Organization) As Standard ( $\mathrm{As}=0.01 \mathrm{mg} / \mathrm{L})$ and $2.3 \%$ exceeded the Nepal Interim As Standard (As $=0.05 \mathrm{mg} / \mathrm{L})($ WHO 2008; Thakur et al. 2011). IRIN (2010) reported that UNICEF had tested over 1.1 million wells in the Terai and found that $1.8 \%$ exceeded the Nepal Interim As Standard, while another 5.6\% exceeded only the WHO As Standard. It is estimated that there are perhaps 200,000 tubewells in the Terai Zone and that 3.5 million Nepalis have no access to drinking water that does not exceed the WHO As Standard (Pokhrel et al. 2009). Other studies in the Terai have addressed the geologic setting of As contamination (Shrestha et al. 2004; Williams et al. 2004, 2005; Brikowski et al. 2005; Gurung et al. 2005; Van Geen et al. 2008), the health impacts of As-contaminated groundwater upon the local population (Ahmad et al. 2004; Maharjan et al. 2005, 2006, 2007) and the As contamination of soils and crops (Dahal et al. 2008).

The dominant paradigm for As contamination of groundwater in south Asia is the reductive-dissolution model, according to which the strongly reducing conditions of the thick sedimentary package of the Indo-Gangetic Plain cause the release of As from sorption sites on Fe oxyhydroxides 
after dissolution of the Fe oxyhydroxides by micro-organisms (Nickson et al. 2000; McArthur et al. 2001; Bose and Sharma 2002; Harvey et al. 2002) or after reduction of adsorbed As from $\mathrm{As}^{+5}$ (arsenate) to $\mathrm{As}^{+3}$ (arsenite) (Bose and Sharma 2002). The important implication of the reductive-dissolution model is that As contamination does not result from even indirect human activity and that nothing can be done to reduce the input of As into aquifers. (However, the input of organicrich water from irrigated fields and constructed ponds may provide the carbon source for reductive dissolution (Charlet and Polya 2006)). A competing model has been the sulfideoxidation model, according to which either overpumping of aquifers or naturally oxidizing conditions has caused oxidation of sulfide minerals and release of co-precipitated As into groundwater (Badal et al. 1996; Mallick and Rajgopal 1996). Williams et al. $(2004,2005)$ has argued that As contamination in the Terai Zone could result from sulfide oxidation rather than reductive dissolution. Polizzotto et al. (2006) has produced a cogent criticism of the reductive-dissolution model based upon
(2005) and Emerman et al. (2007, 2011) found elevated As in rivers in Kathmandu Valley and throughout central and eastern Nepal outside of the Higher Himalayan Zone. Emerman (2005) measured fluvial As six times monthly in eight rivers in Kathmandu Valley and found mean fluvial As exceeding the WHO As Standard in all but one river. Emerman (2005) and Emerman et al. (2007) also collected 115 fluvial samples from 30 locations outside of Kathmandu Valley and the Higher Himalayan Zone and found that $53 \%$ of samples met or exceeded the WHO As Standard. Emerman et al. (2011) measured fluvial As from the Himalaya to the Ganges River floodplain along a 288-km traverse of the Sunkoshi River to the Saptakoshi River. They found that, upstream from the Ganges River floodplain, $45 \%$ of fluvial samples met or exceeded the WHO As Standard, while As concentrations fell to undetectable within the Ganges River floodplain. By contrast, the global background fluvial As is in the range $0.00013-0.0021 \mathrm{mg} / \mathrm{L}$ (Smedley and Kinniburgh 2002). Emerman et al. (2007, 2010, $2011,2013)$ questioned whether it could be a coincidence that

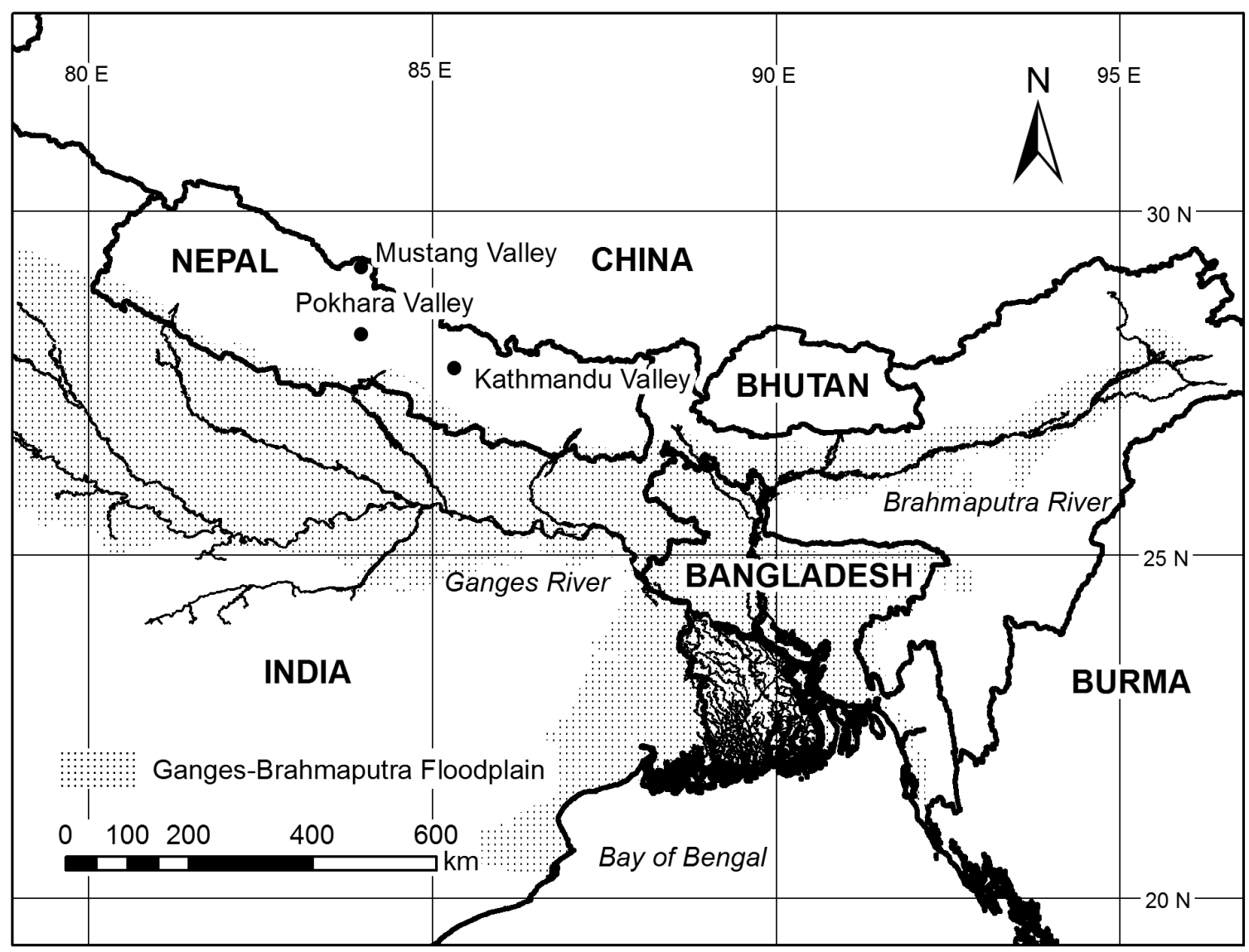

Fig. 1: Kathmandu, Mustang and Pokhara Valleys are three major tectonic valleys far upstream from the Ganges River floodplain in which As contamination of groundwater has been well-documented. Base map data are from Hearn et al. (2001).

observations and experiments on sediments from Bangladesh.

What both the reductive-dissolution and sulfide-oxidation models have in common is that they draw attention to the environmental conditions existing in the soil or sedimentary package and have no role for fluvial As. However, Emerman rivers with elevated As are draining into sedimentary basins in which the groundwater has elevated As. They suggested that while both the reductive-dissolution and sulfide-oxidation models could be thermodynamically plausible, the kinetics could be sufficiently slow that the groundwater chemistry 
simply reflects the surface water chemistry. This reasoning led to the fluvial recharge model for As contamination of groundwater, according to which groundwater is recharged by losing streams with elevated As due to rapid erosion caused by monsoon climate, tectonic uplift and the anthropogenic impacts of deforestation and rangeland degradation.

Rapid erosion should lead to increased concentrations of all elements in rivers because, as the rate of erosion increases, a given volume of rainfall will result in the release of a larger mass of each element from rock, sediment or soil into overland flow, whether the rapid erosion is due to the high-intensity rainfall events of monsoon climate, the steep slopes resulting from tectonic uplift or the lack of surface cover resulting from deforestation or excessive grazing. A similar argument explains why rivers become more turbid as the river stage rises (Bloom 1998). The above argument should apply especially to As, which occurs in dissolved fluvial form predominantly as the arsenate oxyanion $\mathrm{HAsO}_{4}^{-2}$ (Smedley and Kinniburgh 2002). Most ions will tend to adsorb onto sediment during the course of overland flow. Much of the sediment that is eroded from a watershed will not exit the mouth of the watershed, but will be redistributed throughout the watershed, in accordance with the geomorphic principle that smaller landforms erode faster than larger landforms (Bloom 1998). On that basis, much of the mass of elements that are released into overland flow during rapid erosion will not appear in rivers, although most of the water involved in overland flow will appear in rivers. However, the As oxyanion will not tend to adsorb onto sediment during rapid overland flow. First, sediment tends to have many fewer positively-charged sorption sites than negatively-charged sorption sites. Second, the As oxyanion has both much greater mass and volume than the elements that occur in aqueous form as cations or monatomic anions, and greater mass than other common oxyanions such as nitrate $\mathrm{NO}_{3}^{-}$and phosphate $\mathrm{PO}_{4}^{-3}$. Since all ions in overland flow are travelling with the same velocity, the As oxyanion will have much greater kinetic energy than the other ions and will tend to "bounce" off of sorption sites. To put it in another way, a divalent As oxyanion cannot attach to two positively-charged sorption sites unless it has sufficient residence time in the vicinity of the sorption sites for both sites to become simultaneously vacant, for example, by diffusion of two monovalent chloride ions from sorption sites into water. Moreover, the large volume of the As oxyanion implies that the region of the two sorption sites must be sufficiently large for the As oxyanion to attach. The result is that the As oxyanion cannot attach to sorption sites when the overland flow is rapid so that most of the As that is released into overland flow by rainfall will appear in rivers rather than be adsorbed onto sediment that is deposited within the watershed.

Recent studies have shown that elevated As in groundwater is not confined to the Terai Zone of Nepal, but occurs even in Kathmandu Valley, a tectonic valley well upstream from the Ganges River floodplain (Fig. 1) (Khatiwada et al. 2002; Gurung et al. 2006; Bajracharya et al. 2007; Warner et al. 2008; Chapagain et al. 2009; Maharjan et al. 2009; Emerman et al. 2010; Thakur et al. 2011). For example, Emerman et al. (2010) found As levels exceeding the Nepal Interim As Standard in 33\% of 27 groundwater samples. Emerman et al. (2010) tested the fluvial recharge model by comparing the As concentrations of groundwater samples with 48 river samples obtained in a previous study in Kathmandu Valley (Emerman 2005). They found that the geometric mean As concentration of groundwater (As $=0.015$ $\mathrm{mg} / \mathrm{L}$ ) was statistically indistinguishable from the geometric mean As concentration of surface water (As $=0.013 \mathrm{mg} / \mathrm{L}$ ). Emerman et al. (2010) also tested the reductive-dissolution and sulfide-oxidation models by comparing the concentration of As in groundwater with concentrations of sulfide-forming transition elements $(\mathrm{Fe}, \mathrm{Cu}, \mathrm{Mn}, \mathrm{Ni}, \mathrm{Co}, \mathrm{Zn}, \mathrm{Cr})$. Arsenic was uncorrelated with either Fe $\left(R^{2}=0.10\right), M n\left(R^{2}=0.0004\right)$, or any combination of the transition elements $\left(\mathrm{R}^{2}<0.08\right)$, which is inconsistent with both models. The reductive-dissolution model predicts positive relations between As and both Fe and $\mathrm{Mn}$, due to the breakdown of $\mathrm{Fe}$ oxyhydroxides and release of As under reducing conditions, and the lack of dissolved Mn that should occur under oxidizing conditions (Van Geen et al. 2008).

The findings that elevated groundwater As occurred outside of the Terai Zone and that the geochemical data were inconsistent with both the reductive-dissolution and sulfideoxidation models were so startling that it was decided to repeat and extend the Kathmandu Valley study (Emerman et al. 2010) in Pokhara Valley, the second most heavily populated tectonic valley in Nepal after Kathmandu Valley (Fig. 1) (Emerman et al. 2013). Although Kathmandu Valley lies outside of the Ganges floodplain, the abundance of lacustrine clays makes a reducing subsurface environment likely (Gurung et al. 2006), so that Kathmandu Valley could act as a miniature version of the Ganges floodplain. On the other hand, the sediments of Pokhara Valley are dominated by coarse-grained debris flow deposits of limestone, schist, gneiss and granite (Fort and Gupta 1981; Fort and Freytet 1982; Koirala and Rimal 1996; Koirala et al. 1997, 1998) in which an oxidizing subsurface environment is highly likely so that Pokhara Valley is the area where elevated As due to reductive dissolution should be least expected. On the other hand, the abundance of carbonaceous sediments could promote As mobilization due to the reduction in number of positively-charged sorption sites that occur at higher $\mathrm{pH}$.

Despite the differences in subsurface lithology, results from Pokhara Valley were very similar to those from Kathmandu Valley (Emerman et al. 2010, 2013). The Nepal Interim As Standard was exceeded in $53 \%$ of 38 groundwater samples and $74 \%$ of 19 surface water samples, while the WHO As Standard was exceeded in all samples except for one stream. The As concentration of all surface water (geometric mean As $=0.067 \mathrm{mg} / \mathrm{L}$ ) was statistically indistinguishable from that of all groundwater (geometric mean As $=0.086 \mathrm{mg} / \mathrm{L}$ ), which is consistent with the fluvial recharge model. Groundwater As was uncorrelated with either Fe $\left(R^{2}=0.15\right), M n\left(R^{2}=0.02\right)$, sulfate $\mathrm{SO}_{4}^{-2}\left(\mathrm{R}^{2}=0.06\right)$ or any combination of the transition 
elements $\left(\mathrm{R}^{2} \leq 0.15\right)$, which is inconsistent with both the reductive-dissolution and sulfide-oxidation models. The lack of correlation between groundwater $\mathrm{pH}$ and groundwater As $\left(\mathrm{R}^{2}=0.005\right)$ makes it unlikely that elevated As results from the relatively alkaline subsurface environment (mean groundwater $\mathrm{pH}=7.15$ ) of Pokhara Valley.

Based on the above results it was decided to again repeat this study in Mustang Valley, the third major tectonic valley in Nepal (Fig. 1), also known as Upper Mustang (the portion of Mustang District north of Jomsom) and geologically as Thakkhola Graben or Thakkhola-Mustang Graben. Mustang Valley is not affected by the monsoon climate as it lies in the rain shadow north of the Himalayan Range with mean annual rainfall less than $300 \mathrm{~mm}$ (Chhetri 2006). However, steep slopes do result from active east-west extension and the fluvial downcutting that has occurred over the past 7500 years, based upon ${ }^{14} \mathrm{C}$ dates from terraces of the Kali Gandaki Nadi (Fig. 2) (Hurtado et al. 2001). Only 3.4\% of Mustang District is currently forested. The southern portion of Upper Mustang was mostly forested until $4500 \mathrm{yr}$ BP based on charcoal, plant fossils and carbon isotope data from paleosols (Saijo and Tanaka 2002). According to Boselli et al. (2005), extensive deforestation of Mustang Valley was carried out by the Khampas (Tibetan refugees) after the occupation of Tibet in 1951, but this does not appear to have been studied systematically. Currently, firewood is so scarce that dung must be burned as fuel so that it is not available for fertilizer (Chhetri 2006). The majority (41\%) of the land in Mustang District is rangeland, while another $40 \%$ is bare rock (Chhetri 2006). Paudel and Anderson (2010) have documented degradation of the rangeland that is not related to variation in precipitation. Chhetri (2006) has suggested that overgrazing in Mustang Valley has resulted from the closure of the Chinese border to livestock movement that occurred in 1988. The Thakkhola Graben is filled with over $870 \mathrm{~m}$ of continental sandstones and conglomerates with minor limestones and mudstones on top of the Tibetan Sedimentary Sequence (Baade et al. 1998; Adhikari and Wagreich 2011a).

The specific goals of this study were:

1) to determine whether elevated As occurs in surface water or groundwater in Mustang Valley, with particular attention to sources of drinking water,

2) to test the fluvial recharge model by comparing concentrations of As in surface water and groundwater,

3 ) to test the reductive-dissolution model by comparing As concentrations with $\mathrm{Fe}, \mathrm{Mn}$ and sulfate concentrations in groundwater,

4) to test the sulfide-oxidation model by comparing As concentrations with concentrations of sulfate and the transition elements that are normally associated with As, and

5) to determine whether there is spatial clustering of As concentrations.

The only previous studies of hydrology or water quality in Mustang Valley have examined major ion chemistry and $\mathrm{H}$,
$\mathrm{O}, \mathrm{C}$ and $\mathrm{Sr}$ isotope compositions in streams (France-Lanord et al. 1994), bacterial counts in public water taps (Boselli et al. 2005), and biological indicators for stream degradation (Boselli et al. 2005). This study has built upon previous studies in Mustang Valley in the related fields of geomorphology and natural hazards (Fort 1987; Upreti and Yoshida 2005; Fort 2010), tectonics (Colchen et al. 1980; Fort et al. 1982; Yoshida et al. 1984; Colchen 1998, 1999; Garzione et al. 2000a, 2000b, 2003; Chamlagain and Hayashi 2006) and sedimentology (Fort et al. 1981; Fort 1985).

\section{MATERIALS AND METHODS}

In May 2011 water samples were collected in Mustang Valley along the trekking route from Jomsom to the border with China from 33 surface water sites (24 collected directly from streams and 9 collected from canals, pipes or taps fed by streams) and 24 groundwater sites (10 collected directly from springs and 14 collected from pipes or taps fed by springs) (Tables 1a, 2a, Fig. 2) (Note that, at the scale of Fig. 2, many sampling sites cannot be differentiated due to their close proximity.) Based on many conversations with local residents, including Jigme Dorje Palbar Bista, the King of Mustang (an unofficial ceremonial post since 2008), there are no handdug or drilled wells anywhere in Mustang Valley. Water temperature and $\mathrm{pH}$ were measured on site with the Hach EC-10 pH Meter. Electrical conductivity (EC) was measured on site with the Hanna HI 8033 Multi-Range Conductivity Meter. Locations were measured with the Trimble Juno SB GPS Receiver. Water samples were collected in $250-\mathrm{mL}$ and $125-\mathrm{mL}$ polyethylene containers with the contents of the larger container used for measurement of As and the other used for all other heavy metals and sulfate. Duplicate samples were not collected due to the large volume of water required for analysis by the spectrophotometric method and the need to carry all water samples on horseback.

Although previous As studies in Nepal by the authors (Emerman et al. 2010, 2011, 2013) involved forcing water samples through $0.45-\mu \mathrm{m}$ syringe filters for measurement of dissolved As and other heavy metals, water samples were not filtered for this study. The primary objective of this study was to assess the quality of drinking water and local residents would not be forcing drinking water through ultrafine filters. On the other hand, no one would intentionally drink sediment, but would first allow the sediment to settle. After the samples were returned to Utah Valley University within four weeks of collection, they were allowed to settle for 24 hours (Salbu et al. 1979) and the clear water was poured into new containers. Although some transfer of As between aqueous and sediment phases within the sample containers was possible prior to settling, only five samples contained visible sediment after collection. Of these five samples, three had undetectable As and the maximum As concentration was As $=0.003 \mathrm{mg} / \mathrm{L}$. The avoidance of ultrafine filtering also met the secondary objective of assessing the tendency of surface water As to be transferred to groundwater As. The fluvial As that could move into groundwater would include not only dissolved As, but also 
Table 1a: Description, arsenic concentrations and on-site measurements of surface water sampling sites

\begin{tabular}{|c|c|c|c|c|c|c|c|}
\hline $\begin{array}{c}\text { As } \\
\text { Rank }^{1} \\
\end{array}$ & $\begin{array}{c}\mathrm{As} \\
(\mathrm{mg} / \mathrm{L})\end{array}$ & Location & $\begin{array}{l}\text { Latitude }^{2} \\
\left({ }^{\circ} \mathbf{N}\right) \\
\end{array}$ & $\begin{array}{c}\text { Longitude }^{2} \\
(\mathrm{O} E)\end{array}$ & $\begin{array}{l}\text { Temp } \\
\left({ }^{\circ} \mathbf{C}\right) \\
\end{array}$ & $\mathbf{p H}$ & $\begin{array}{c}\mathbf{E C} \\
(\mu \mathrm{S} / \mathrm{cm}) \\
\end{array}$ \\
\hline 1 & 0.848 & Kimaling Khola ${ }^{3}$ & 29.21035694 & 83.97173111 & 21.0 & 8.70 & 127.7 \\
\hline 2 & 0.295 & Ghami Khola Tributary & 29.06131071 & 83.87664669 & 23.8 & 8.90 & 461 \\
\hline 3 & 0.218 & Hyujung Khola & 29.25405806 & 83.96060194 & 10.6 & 8.60 & 81.4 \\
\hline 4 & 0.210 & Ghami Khola & 29.06139320 & 83.87607687 & 18.6 & 8.84 & 211 \\
\hline 5 & 0.197 & Chhungma Khola & 29.23656611 & 83.96549278 & 14.8 & 8.86 & 44.0 \\
\hline 6 & 0.164 & Kali Gandaki Nadi Tributary & 28.79098190 & 83.73457928 & -4 & - & 443 \\
\hline 7 & 0.156 & Nhichung Khola Tributary & 29.19748750 & 83.96371222 & 22.2 & 8.80 & 241 \\
\hline 8 & 0.126 & Dokpolo Khola ${ }^{5}$ & 29.18068778 & 83.95542861 & 13.8 & 8.21 & 391 \\
\hline 9 & 0.112 & Thulung Khola & 29.14591417 & 83.94466667 & 17.2 & 8.69 & 271 \\
\hline 10 & $0.075^{6}$ & Kali Gandaki Nadi & 28.78353444 & 83.72780759 & - & $-\overline{-}$ & 576 \\
\hline 11 & 0.026 & Charang Khola & 29.10424260 & 83.92955384 & $2 \overline{1} . \overline{8}$ & 8.37 & 330 \\
\hline 12 & 0.023 & Charang Khola ${ }^{5}$ & 29.09237152 & 83.93253998 & 20.8 & 8.59 & 272 \\
\hline 13 & 0.020 & Charang Khola ${ }^{5}$ & 29.09313801 & 83.93235308 & 19.7 & 8.68 & 244 \\
\hline 14 & 0.018 & Charang Khola ${ }^{5}$ & 29.09289071 & 83.93183028 & 22.3 & 8.72 & 329 \\
\hline 15 & 0.014 & Thulung Khola Tributary & 29.15416667 & 83.91666667 & - & 8.78 & 246 \\
\hline 16 & 0.003 & Panda Khola & 28.80686046 & 83.76749795 & 15.6 & 8.75 & 650 \\
\hline 17 & 0.002 & Dhingklo Khola ${ }^{5}$ & 28.89089531 & 83.80617547 & 15.4 & 8.56 & 560 \\
\hline 18 & 0.000 & Jhong Khola & 28.83721028 & 83.78441308 & 14.7 & 8.42 & 525 \\
\hline 19 & 0.000 & Dhakmar Khola & 29.09134182 & 83.87865317 & 16.1 & 8.52 & 431 \\
\hline 20 & 0.000 & Naktang Khola & 29.07150556 & 83.84785278 & - & 8.52 & 305 \\
\hline 21 & 0.000 & Ghami Khola & 29.07134444 & 83.84791944 & - & 8.62 & 169 \\
\hline 22 & 0.000 & Kali Gandaki Nadi Tributary & 29.01736091 & 83.84755062 & 18.6 & 8.90 & 169 \\
\hline 23 & 0.000 & Kali Gandaki Nadi Tributary & 29.00587878 & 83.84766164 & 15.6 & 8.80 & 190 \\
\hline 24 & 0.000 & Yamta Khola & 29.00434410 & 83.84694858 & 16.4 & 8.88 & 223 \\
\hline 25 & 0.000 & $\begin{array}{l}\text { Syangboche Khola } \\
\text { Tributary }^{5}\end{array}$ & 28.98587912 & 83.81350675 & 14.9 & 8.18 & 179 \\
\hline 26 & 0.000 & Bhena Khola & 28.98270000 & 83.80927778 & 13.7 & 8.39 & 206 \\
\hline 27 & 0.000 & Jhuwa Khola & 28.96796944 & 83.80241389 & 18.1 & 8.48 & 255 \\
\hline 28 & 0.000 & Samar Khola & 28.96352888 & 83.80197994 & 19.7 & 8.46 & 190 \\
\hline 29 & 0.000 & Ghyaka Khola $^{5}$ & 28.93570609 & 83.81255416 & 18.0 & 8.46 & 234 \\
\hline 30 & 0.000 & Ghyaka Khola $^{5}$ & 28.93096343 & 83.82693950 & 18.6 & 8.34 & 255 \\
\hline 31 & 0.000 & Kali Gandaki Nadi & 28.92700819 & 83.82843626 & 19.6 & 8.24 & 644 \\
\hline 32 & 0.000 & Narsing Khola & 28.91542635 & 83.82051719 & 19.0 & 8.36 & 941 \\
\hline 33 & - & Chhorak Dokpa Khola & 29.18544639 & 83.95535667 & 23.3 & 8.71 & 236 \\
\hline
\end{tabular}

${ }^{1}$ As Rank refers to the ranking of all surface water samples from highest to lowest As concentration.

${ }^{2}$ Latitude and longitude are based upon WGS 84 coordinate system.

${ }^{3}$ Khola and nadi are the Nepali words for a smaller and larger river, respectively. Names of rivers follow Nepal Map Publisher (n.d.).

${ }^{4}$ Missing $\mathrm{pH}$ and temperature values resulted because either the $\mathrm{pH}$ meter was not functioning or the temperature could not be measured quickly enough. The missing As value resulted from collection of insufficient sample.

${ }^{5}$ Sample was collected not from the river itself, but from a tap, canal or pipe fed by the river.

${ }^{6}$ Arsenic values above the dashed line exceed the Nepal Interim As Standard (As $=0.05 \mathrm{mg} / \mathrm{L}$ ). 
Table 1b: Geochemistry of surface water sites

\begin{tabular}{|c|c|c|c|c|c|c|c|c|}
\hline $\begin{array}{c}\text { As } \\
\text { Rank }^{1}\end{array}$ & $\mathrm{Fe}(\mathrm{mg} / \mathrm{L})$ & $\mathrm{Cu}(\mathrm{mg} / \mathrm{L})$ & Mn (mg/L) & $\mathrm{SO}_{4}(\mathrm{mg} / \mathrm{L})$ & $\mathrm{Zn}(\mathrm{mg} / \mathrm{L})$ & $\mathrm{Co}(\mathrm{mg} / \mathrm{L})$ & $\mathrm{Ni}(\mathrm{mg} / \mathrm{L})$ & $\mathrm{Cr}(\mathrm{mg} / \mathrm{L})$ \\
\hline 1 & 0.28 & 0.33 & 0.0 & 0 & 0.16 & 0.043 & $0.348^{*}$ & $0.23^{*}$ \\
\hline 2 & 0.09 & 0.00 & $1.0^{*}$ & 58 & 0.14 & 0.025 & 0.004 & 0.02 \\
\hline 3 & 0.00 & 0.18 & 0.0 & 0 & 0.42 & 0.009 & 0.000 & 0.03 \\
\hline 4 & 0.02 & 0.00 & $1.5^{*}$ & 43 & 0.18 & 0.007 & 0.007 & 0.02 \\
\hline 5 & 0.00 & 0.02 & 0.3 & 1 & 0.13 & 0.001 & 0.010 & 0.02 \\
\hline 6 & 0.00 & 0.00 & $0.5^{*}$ & $260 *$ & 0.09 & 0.010 & 0.000 & 0.04 \\
\hline 7 & $0.36^{*}$ & 0.04 & $4.7^{*}$ & 1 & 0.12 & 0.004 & 0.000 & 0.00 \\
\hline 8 & 0.01 & 0.10 & $1.0^{*}$ & 44 & 0.13 & 0.133 & 0.018 & 0.01 \\
\hline 9 & 0.01 & 0.03 & $0.9^{*}$ & 47 & 0.18 & 0.163 & 0.044 & 0.01 \\
\hline 10 & $0.31^{*}$ & 0.00 & 0.0 & 170 & 0.04 & 0.019 & 0.008 & 0.03 \\
\hline 11 & 0.01 & 0.06 & $1.2^{*}$ & 54 & 0.00 & 0.045 & 0.000 & 0.01 \\
\hline 12 & 0.01 & 0.10 & $0.9^{*}$ & 64 & 0.07 & 0.000 & 0.000 & 0.01 \\
\hline 13 & 0.02 & 0.03 & $1.2^{*}$ & 65 & 0.11 & 0.034 & 0.001 & 0.02 \\
\hline 14 & 0.00 & 0.02 & 0.1 & 65 & 0.12 & 0.001 & 0.032 & 0.01 \\
\hline 15 & 0.03 & 0.04 & $0.9^{*}$ & 54 & 0.13 & 0.000 & 0.019 & 0.02 \\
\hline 16 & $2.07^{*}$ & 0.00 & $2.1^{*}$ & $320^{*}$ & 0.12 & 0.000 & 0.000 & $0.07^{*}$ \\
\hline 17 & 0.27 & 0.04 & $2.0^{*}$ & $320^{*}$ & 0.03 & 0.025 & 0.010 & $0.08^{*}$ \\
\hline 18 & 0.12 & 0.00 & $1.7^{*}$ & $280^{*}$ & 0.04 & 0.010 & 0.000 & 0.03 \\
\hline 19 & 0.03 & 0.06 & $0.6^{*}$ & 130 & 0.17 & 0.003 & 0.000 & 0.02 \\
\hline 20 & 0.01 & 0.00 & $0.6^{*}$ & 61 & 0.12 & 0.003 & 0.004 & 0.02 \\
\hline 21 & 0.01 & 0.00 & $0.9^{*}$ & 34 & 0.00 & 0.000 & 0.004 & 0.00 \\
\hline 22 & 0.02 & 0.00 & $2.2^{*}$ & 25 & 0.11 & 0.020 & 0.000 & 0.04 \\
\hline 23 & 0.03 & 0.00 & $2.9^{*}$ & 27 & 0.08 & 0.030 & 0.000 & 0.03 \\
\hline 24 & 0.05 & 0.00 & $1.6^{*}$ & 24 & 0.20 & 0.011 & 0.002 & 0.02 \\
\hline 25 & 0.00 & 0.00 & $0.7^{*}$ & 25 & 0.07 & 0.010 & 0.003 & 0.03 \\
\hline 26 & 0.01 & 0.00 & $0.5^{*}$ & 32 & 0.07 & 0.020 & 0.006 & 0.00 \\
\hline 27 & 0.00 & 0.05 & $0.7^{*}$ & 34 & 0.11 & 0.020 & 0.000 & 0.02 \\
\hline 28 & 0.03 & 0.00 & 0.0 & 33 & 0.07 & 0.000 & 0.029 & 0.01 \\
\hline 29 & 0.00 & 0.07 & $0.5^{*}$ & 51 & 0.10 & 0.000 & 0.003 & 0.03 \\
\hline 30 & 0.00 & 0.00 & 0.0 & 45 & 0.07 & 0.010 & 0.008 & 0.02 \\
\hline 31 & $1.32 *$ & 1.13 & 0.4 & $260^{*}$ & 0.29 & 0.115 & 0.021 & 0.01 \\
\hline 32 & $4.00 *$ & $2.08^{*}$ & $2.0^{*}$ & $450^{*}$ & 0.35 & 1.189 & $0.106^{*}$ & $0.26^{*}$ \\
\hline 33 & 0.11 & 0.03 & 0.3 & 33 & 0.28 & 0.011 & 0.000 & 0.00 \\
\hline
\end{tabular}

${ }^{1}$ See Table 1a.

${ }^{*}$ Concentration exceeds the WHO Standard $(\mathrm{Cu}=2 \mathrm{mg} / \mathrm{L}, \mathrm{Mn}=0.4 \mathrm{mg} / \mathrm{L}, \mathrm{Ni}=0.07 \mathrm{mg} / \mathrm{L}, \mathrm{Cr}=0.05 \mathrm{mg} / \mathrm{L})$ or the Nepal National Drinking Water Quality Standard ( $\mathrm{Fe}=0.3 \mathrm{mg} / \mathrm{L}, \mathrm{Zn}=3 \mathrm{mg} / \mathrm{L}, \mathrm{SO}_{4}=250 \mathrm{mg} / \mathrm{L}$ ) (WHO 2008; Warner et al. 2008).

As adsorbed onto very fine particles. (According to Sanders (1998), there is no agreement as to when samples should be filtered or whether samples should ever be filtered. See Saar (1997) for the history and advantages and disadvantages of filtering water samples.) Water samples were refrigerated as soon as they were returned to Utah Valley University and until they were analysed in order to minimize any microbial action that would transfer solutes between solid and aqueous phases. Samples were refrigerated as opposed to being acidified for preservation and then de-acidified for analysis in order to avoid the errors that could be introduced by excessive chemical processing (Saar 1997).

Concentrations of $\mathrm{Fe}, \mathrm{Cu}, \mathrm{Mn}, \mathrm{Zn}, \mathrm{Co}, \mathrm{Ni}, \mathrm{Cr}$ and sulfate were measured using the Hach DR-2700 Spectrophotometer. Water samples were analyzed for As using the silver diethyldithiocarbamate method (U.S. Environmental Protection Agency Standard Method 3500-As B) (Rice et al. 2012; Hach Company 2013) with the same spectrophotometer. For the first 24 samples, the As absorbing solution was prepared by dissolving $5.00 \mathrm{~g}$ silver diethyldithiocarbamate in $1000 \mathrm{~mL}$ pyridine (Hach Company 2013), after which the As absorbing solution was prepared by dissolving $2.50 \mathrm{~g}$ silver diethyldithiocarbamate and $1.64 \mathrm{~g}$ 1-ephedrine in 1000 $\mathrm{mL}$ chloroform (Kopp 1973). The spectrophotometer was recalibrated after every 10 As measurements using four standard solutions with As concentrations of 0.000, 0.020, 0.040 and 
$0.200 \mathrm{mg} / \mathrm{L}$. The coefficient of variation (ratio of standard deviation to mean) of the silver diethyldithiocarbamate method is $6.6 \%$ for $0.005 \mathrm{mg}$ As (equivalent to As $=0.020 \mathrm{mg} / \mathrm{L}$ based on the $250 \mathrm{~mL}$ of sample required by the Hach Company (2013) distillation apparatus) according to Marshall (1978) and $<10 \%$ for $0.010 \mathrm{mg}$ As (equivalent to As $=0.040 \mathrm{mg} / \mathrm{L}$ based on 250 $\mathrm{mL}$ of sample) according to Rice et al. (2012), which may be regarded as measures of the precision or reproducibility of the method. Based on the six calibrations carried out for this study, the RMSE (root mean square error) of the method is As $=0.011$ $\mathrm{mg} / \mathrm{L}$ or $12.6 \%$ based on average As $=0.089 \mathrm{mg} / \mathrm{L}$. Whenever the As concentration of a sample exceeded As $=0.220 \mathrm{mg} / \mathrm{L}$, the reacted As absorbing solution was diluted with unreacted As absorbing solution until the As concentration of the mixture was less than As $=0.220 \mathrm{mg} / \mathrm{L}$. All analyses were completed within six months of sampling. The detection limits were 0.001 $\mathrm{mg} / \mathrm{L}$ for As, $\mathrm{Ni}$ and $\mathrm{Co}, 0.01 \mathrm{mg} / \mathrm{L}$ for $\mathrm{Fe}, \mathrm{Cu}, \mathrm{Zn}$ and $\mathrm{Cr}, 0.1$ $\mathrm{mg} / \mathrm{L}$ for $\mathrm{Mn}$ and $1 \mathrm{mg} / \mathrm{L}$ for sulfate. Due to some processing errors, there was insufficient water for measurement of As in one sample and some of the transition elements in another sample (Tables 1a, 2b).

Table 2a: Description, arsenic concentrations and on-site measurements of groundwater sampling sites ${ }^{1}$

\begin{tabular}{|c|c|c|c|c|c|c|c|}
\hline $\begin{array}{c}\text { As } \\
\text { Rank }^{2} \\
\end{array}$ & $\begin{array}{c}\mathrm{As} \\
(\mathrm{mg} / \mathrm{L})\end{array}$ & Location & $\begin{array}{c}\text { Latitude }^{3} \\
\left({ }^{\circ} \mathrm{N}\right)\end{array}$ & $\begin{array}{c}\text { Longitude }^{3} \\
\left({ }^{\circ} \mathbf{E}\right)\end{array}$ & $\begin{array}{c}\text { Temp } \\
\left({ }^{\circ} \mathrm{C}\right)\end{array}$ & pH & $\begin{array}{c}\mathrm{EC} \\
(\mu \mathrm{S} / \mathrm{cm})\end{array}$ \\
\hline 1 & 0.436 & Lo-Manthang $^{4}$ & 29.18287556 & 83.95785306 & 13.4 & 8.88 & 284 \\
\hline 2 & 0.280 & Dhakmar & 29.09068691 & 83.87784900 & 18.5 & 8.39 & 325 \\
\hline 3 & 0.224 & Lo-Manthang ${ }^{4}$ & 29.18310778 & 83.95722444 & 13.3 & 8.77 & 283 \\
\hline 4 & 0.221 & Ghami & 29.06101740 & 83.87572392 & 14.7 & 8.52 & 331 \\
\hline 5 & 0.220 & Charang & 29.10445651 & 83.92923910 & 22.0 & 7.88 & 449 \\
\hline 6 & 0.204 & Lo-Manthang ${ }^{4}$ & 29.18347889 & 83.95693278 & 13.4 & 8.86 & 284 \\
\hline 7 & 0.163 & Lo-Manthang ${ }^{4}$ & 29.18166944 & 83.95646861 & 13.9 & 8.88 & 235 \\
\hline 8 & 0.110 & Lo-Manthang ${ }^{4}$ & 29.18354806 & 83.95586167 & 13.0 & 9.13 & 278 \\
\hline 9 & 0.108 & Lo-Manthang $^{4}$ & 29.18257583 & 83.95585611 & 13.5 & 8.82 & 227 \\
\hline 10 & 0.098 & Lo-Manthang $^{4}$ & 29.18397694 & 83.95732611 & 12.9 & 8.62 & 279 \\
\hline 11 & 0.095 & Lo-Manthang ${ }^{4}$ & 29.18286083 & 83.95709389 & 14.1 & 8.43 & 283 \\
\hline 12 & 0.076 & Charang & 29.10424260 & 83.92955384 & 19.5 & 7.84 & 408 \\
\hline 13 & 0.071 & Lo-Manthang ${ }^{4}$ & 29.18189750 & 83.95705861 & 13.8 & 8.70 & 241 \\
\hline 14 & 0.064 & Jomsom & 28.78418176 & 83.73987601 & -5 & - & 851 \\
\hline 15 & $0.063^{6}$ & Nyamdo & 29.24107750 & 83.96549500 & 11.6 & 8.30 & 207 \\
\hline 16 & 0.019 & Ekle Bhatti ${ }^{4}$ & 28.81820371 & 83.77351294 & 19.1 & 8.49 & 510 \\
\hline 17 & 0.018 & Lo-Manthang & 29.15416667 & 83.91666667 & - & 8.73 & 225 \\
\hline 18 & 0.016 & Lo-Manthang & 29.15416667 & 83.91666667 & - & 8.78 & 199 \\
\hline 19 & 0.011 & Dhakmar & 29.08897396 & 83.87986246 & 14.0 & 8.40 & 447 \\
\hline 20 & 0.004 & Ghami & 29.06456591 & 83.85678110 & 11.2 & 8.19 & 220 \\
\hline 21 & 0.001 & Syangboche ${ }^{4}$ & 28.99126960 & 83.83840706 & 14.6 & 7.82 & 375 \\
\hline 22 & 0.000 & Chhunngar $^{4}$ & 29.02760323 & 83.84836858 & 18.6 & 8.23 & 317 \\
\hline 23 & 0.000 & Tamagaon $^{4}$ & 29.01778355 & 83.84757471 & 17.8 & 8.46 & 322 \\
\hline 24 & 0.000 & Kagbeni $^{4}$ & 28.83646531 & 83.78292165 & 17.9 & 8.16 & 695 \\
\hline
\end{tabular}

${ }^{1}$ All groundwater sampling sites were springs or pipes or taps fed by springs as there are no wells in Mustang Valley.

${ }^{2}$ As Rank refers to the ranking of all groundwater samples from highest to lowest As concentration.

${ }^{3}$ Latitude and longitude are based upon WGS 84 coordinate system.

${ }^{4}$ Sample was collected not from a spring itself, but from a pipe or tap fed by a spring.

${ }^{5}$ Missing $\mathrm{pH}$ and temperature values resulted because either the $\mathrm{pH}$ meter was not functioning or the temperature could not be measured quickly enough.

${ }^{6}$ Arsenic values above the dashed line exceed the Nepal Interim As Standard (As $\left.=0.05 \mathrm{mg} / \mathrm{L}\right)$. 
Table 2b: Geochemistry of groundwater sites

\begin{tabular}{|c|c|c|c|c|c|c|c|c|}
\hline $\mathbf{A s}$ & $\mathbf{F e}(\mathbf{m g} / \mathbf{L})$ & $\mathbf{C u}(\mathbf{m g} / \mathbf{L})$ & $\mathbf{M n}(\mathbf{m g} / \mathbf{L})$ & $\mathbf{S O}_{\mathbf{4}}(\mathbf{m g} / \mathbf{L})$ & $\mathbf{Z n}(\mathbf{m g} / \mathbf{L})$ & $\mathbf{C o}(\mathbf{m g} / \mathbf{L})$ & $\mathbf{N i}(\mathbf{m g} / \mathbf{L})$ & $\mathbf{C r}(\mathbf{m g} / \mathbf{L})$ \\
\hline $\mathbf{R a n k}^{\mathbf{1}}$ & & & & & & & \\
\hline 1 & $0.75^{*}$ & 0.99 & 0.3 & 9 & 0.39 & 0.000 & 0.009 & 0.02 \\
2 & 0.04 & 0.06 & $0.9^{*}$ & 120 & 0.17 & 0.000 & 0.000 & 0.01 \\
3 & 0.10 & $3.10^{*}$ & $12.0^{*}$ & 0 & 0.10 & 0.110 & 0.006 & 0.01 \\
4 & 0.05 & 0.00 & $1.0^{*}$ & 35 & 0.21 & 0.000 & 0.000 & 0.03 \\
5 & 0.01 & 0.03 & $1.3^{*}$ & 43 & 0.16 & 0.158 & 0.019 & 0.01 \\
6 & $--^{2}$ & - & - & 17 & - & - & 0.002 & 0.00 \\
7 & 0.01 & 0.10 & $0.9^{*}$ & 44 & 0.19 & 0.170 & 0.021 & 0.01 \\
8 & $0.51^{*}$ & 1.23 & $2.7^{*}$ & 39 & 0.09 & 0.024 & $0.306^{*}$ & 0.02 \\
9 & $0.72^{*}$ & 0.15 & $2.4^{*}$ & 42 & 0.63 & 0.000 & 0.045 & 0.02 \\
10 & $0.51^{*}$ & 0.99 & 0.3 & 36 & 0.54 & 0.012 & $0.345^{*}$ & 0.01 \\
11 & $0.57^{*}$ & 1.32 & 0.3 & 39 & 0.75 & 0.000 & 0.000 & 0.01 \\
12 & 0.02 & 0.15 & $1.1^{*}$ & 53 & 0.09 & 0.136 & 0.043 & 0.01 \\
13 & 0.06 & 0.02 & 0.3 & 46 & 0.17 & 0.165 & 0.024 & 0.01 \\
14 & 0.00 & 0.00 & $0.5^{*}$ & $350^{*}$ & 0.03 & 0.010 & 0.000 & 0.02 \\
15 & 0.17 & 0.06 & $1.1^{*}$ & 13 & 0.12 & 0.001 & 0.009 & 0.02 \\
16 & 0.01 & 0.07 & $1.1^{*}$ & $360^{*}$ & 0.10 & 0.020 & 0.000 & 0.02 \\
17 & 0.16 & 0.08 & 0.4 & 41 & 0.13 & 0.132 & $0.129^{*}$ & 0.01 \\
18 & $0.81^{*}$ & 0.99 & $3.3^{*}$ & 33 & 0.09 & 0.036 & 0.000 & 0.03 \\
19 & 0.00 & 0.02 & $0.6^{*}$ & 220 & 0.27 & 0.011 & 0.004 & 0.02 \\
20 & 0.00 & 0.10 & $0.5^{*}$ & 14 & 0.24 & 0.001 & 0.000 & 0.05 \\
21 & 0.02 & 0.09 & $1.3^{*}$ & 16 & 0.02 & 0.000 & 0.004 & 0.01 \\
22 & 0.02 & 0.00 & 0.4 & 31 & 0.08 & 0.000 & 0.008 & 0.03 \\
23 & 0.00 & 0.00 & $1.6^{*}$ & 32 & 0.12 & 0.010 & 0.000 & 0.03 \\
24 & 0.01 & 0.01 & $2.0^{*}$ & $500^{*}$ & 0.04 & 0.000 & 0.003 & 0.02 \\
\hline
\end{tabular}

${ }^{1}$ See Table 2a.

${ }^{2}$ Missing concentrations resulted from collection of insufficient sample.

"Concentration exceeds the WHO Standard $(\mathrm{Cu}=2 \mathrm{mg} / \mathrm{L}, \mathrm{Mn}=0.4 \mathrm{mg} / \mathrm{L}, \mathrm{Ni}=0.07 \mathrm{mg} / \mathrm{L}, \mathrm{Cr}=0.05 \mathrm{mg} / \mathrm{L})$ or the Nepal National Drinking Water Quality Standard ( $\mathrm{Fe}=0.3 \mathrm{mg} / \mathrm{L}, \mathrm{Zn}=3 \mathrm{mg} / \mathrm{L}, \mathrm{SO}_{4}=250 \mathrm{mg} / \mathrm{L}$ ) (WHO 2008; Warner et al. 2008).

Although the samples were not filtered prior to analysis, the measured As concentrations were not total As, nor were they only dissolved As. The Hach Company (2013) distillation procedure involves combining $250 \mathrm{~mL}$ of sample with $25 \mathrm{~mL}$ concentrated hydrochloric acid, $3 \mathrm{~mL}$ potassium iodide, $1 \mathrm{~mL}$ stannous chloride and $6.0 \mathrm{~g}$ powdered $\mathrm{Zn}$ in a distillation flask for 45 minutes to create a strongly reducing environment that converts all forms of As into arsine gas, which diffuses into the As absorbing solution to form a red complex. By comparison, by synthesizing the various pools of solid-phase As, Keon et al. (2001) showed that combining sediment with $1 \mathrm{M} \mathrm{HCl}$ for 60 minutes extracted the dissolved As, the ionically bound
As, and the As co-precipitated with acid-volatile sulfides, carbonates, Mn oxides, and very amorphous Fe oxyhydroxides, but not more recalcitrant forms of As. The distillation mixture in the Hach Company (2013) procedure is equivalent to 1.04 $\mathrm{M} \mathrm{HCl}$ so that the measured As concentrations in this study should roughly correspond to the list of labile As phases given by Keon et al. (2001). However, since the vast majority of samples included no visible sediment when first collected, and since the only samples with visible sediment had very low or undetectable As, it is most likely that the measured As concentrations refer almost entirely to dissolved As. The same can most likely be said for all other measured heavy metals and sulfate. 


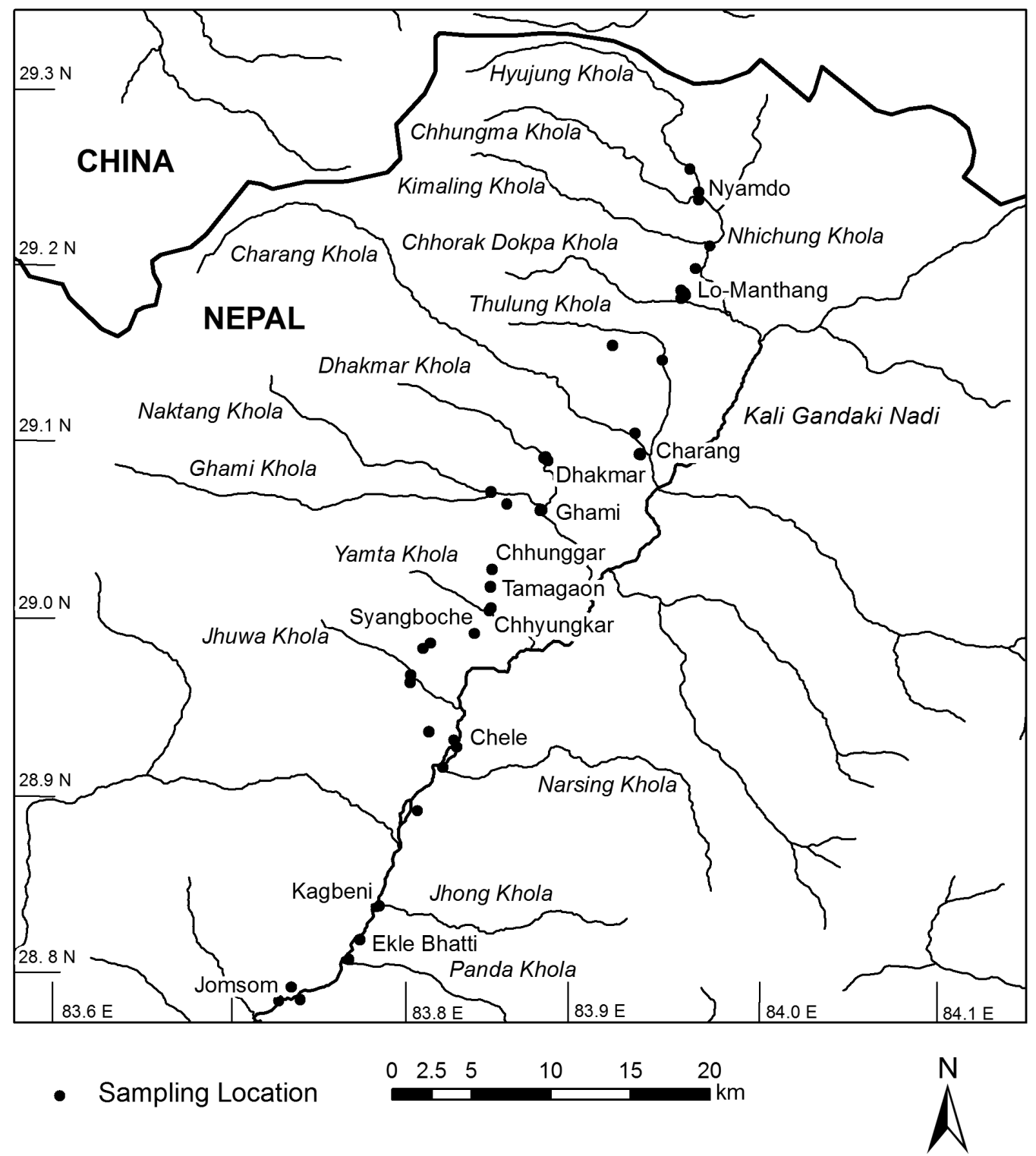

Fig. 2: Water samples were collected from 33 streams and 24 springs in Mustang Valley. (At this scale, many locations cannot be differentiated due to their close proximity.). No wells were found anywhere in Mustang Valley. Rivers follow National Geographic (2013) and spellings follow Nepal Map Publisher (n.d.) with additional base map data from Hearn et al. (2001).

\section{RESULTS}

Out of the 32 surface water sites for which As was measured, 15 (47\%) exceeded the WHO As Standard and 10 (31\%) exceeded the Nepal Interim As Standard (Table 1a). Out of 24 groundwater sites, 19 (79\%) exceeded the WHO As Standard, while $15(63 \%)$ exceeded the Nepal Interim As Standard (Table 2a). Lo-Manthang, the largest village (population about 850) in Mustang Valley (Boselli et al. 2005), has eight public water taps (Groundwater As Ranks 1, $3,6-7,9,11,13)$ and one water tap each in the courtyards of Choedhe Gompa (monastery) (Groundwater As Rank 10) and
Great Compassion Boarding School (Groundwater As Rank 8) (Table 2a). All taps are fed from a tank that mixes water that is piped from two springs from outside Lo-Manthang. One tap was dry, while the As concentration in all of the other nine taps exceeded the Nepal Interim As Standard with geometric mean $\mathrm{As}=0.143 \mathrm{mg} / \mathrm{L}$ and maximum $\mathrm{As}=0.436 \mathrm{mg} / \mathrm{L}$ at a public tap. According to local residents, in the winter they usually take water from a canal fed by Chhorak Dokpa Khola (Surface Water As Rank 33) (Table 1a, Fig. 2) as water from the taps is too cold. Unfortunately, this was the site from which insufficient water was collected for measurement of As. All other sampled public 
water taps in Mustang Valley had As concentrations less than the Nepal Interim As Standard, including three taps in Charang fed by Charang Khola (Surface Water As Ranks 12-14), two taps in Syangboche fed by a spring (Groundwater As Rank 21) and by a tributary to Syangboche Khola (Surface Water As Rank 25), a tap in Chele fed by Ghyaka Khola (Surface Water As Rank 30), and taps fed by springs in Ekle Bhatti (Groundwater As Rank 16), Chhunngar (Groundwater As Rank 22), Tamagaon (Groundwater As Rank 23), and Kagbeni (Groundwater As Rank 24) (Tables 1a, 2a, Fig. 2). The WHO drinking water standards for $\mathrm{Cu}(2 \mathrm{mg} / \mathrm{L}), \mathrm{Mn}(0.4 \mathrm{mg} / \mathrm{L}), \mathrm{Ni}$ $(0.07 \mathrm{mg} / \mathrm{L})$ and $\mathrm{Cr}(0.05 \mathrm{mg} / \mathrm{L})$ were respectively exceeded at one surface water site (3\%) and one groundwater site (4\%), 24 surface water sites $(73 \%)$ and 17 groundwater sites $(74 \%)$, two surface water sites $(6 \%)$ and three groundwater sites $(13 \%)$, and four surface water sites (12\%) and no groundwater sites (WHO 2008) (Tables 1b, 2b). The Nepal National Drinking Water Quality Standards for Fe $(0.3 \mathrm{mg} / \mathrm{L}), \mathrm{Zn}(3 \mathrm{mg} / \mathrm{L})$ and sulfate $(250 \mathrm{mg} / \mathrm{L})$ were respectively exceeded at five surface water sites (15\%) and six groundwater sites (26\%), no surface water or groundwater sites, and six surface water sites $(18 \%)$ and three groundwater sites (13\%) (Warner et al. 2008) (Tables 1b, 2b). (WHO (2008) does not have drinking water standards for $\mathrm{Fe}, \mathrm{Co}, \mathrm{Zn}$ or sulfate.)

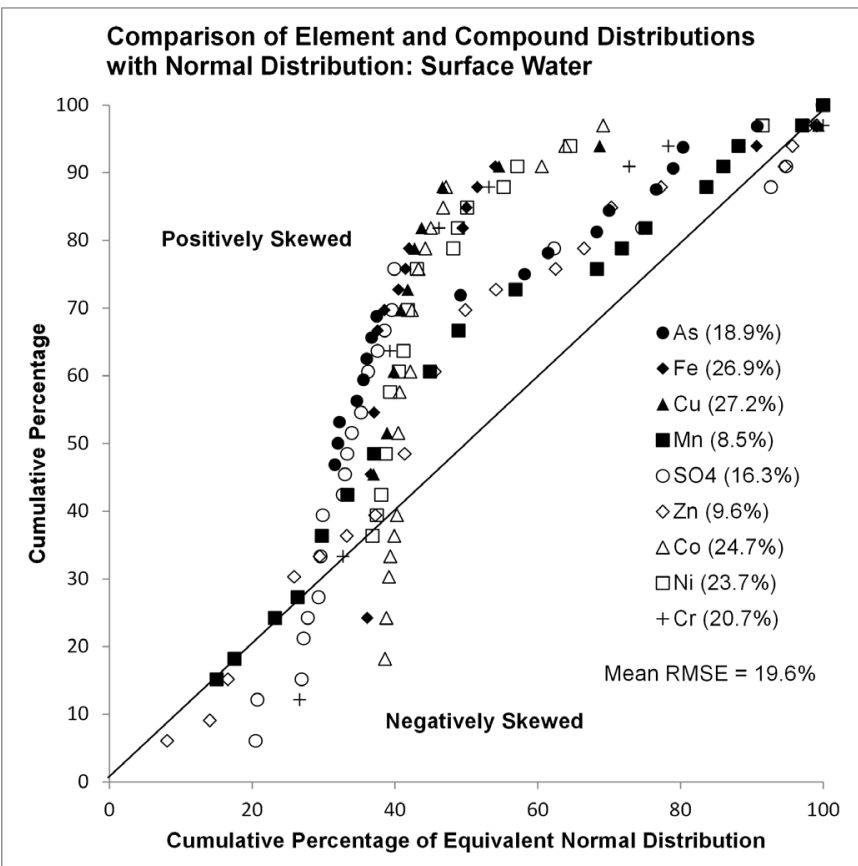

Fig. 3a: A comparison of the cumulative percentage of each element and compound in surface water with the equivalent normal distribution with the same mean and standard deviation showed element and compound distributions to be a moderate fit to a normal distribution. The root mean square error (RMSE) averaged over all parameters was $19.6 \%$ (RMSE for each parameter shown in parentheses).

It is crucial to test for the existence of normal distributions prior to using any statistical tests that assume normal distributions. For each parameter, the mean and standard deviation were calculated and the cumulative percentage for each value (percentage of values equal to or less than that value) were compared with the cumulative percentage for a normal distribution with the same mean and standard deviation. The cumulative percentage of each value of each parameter was also compared with the cumulative percentage of the equivalent lognormal distribution (same mean and standard deviation as the set of logarithms of values). The use of a lognormal distribution requires an assumption about the zero values (values below the detection limit). We set all zero values equal to the detection limit. Samples were below the detection limit for $32 \%$ of As values, $21 \%$ of Fe values, $34 \%$ of $\mathrm{Cu}$ values, $9 \%$ of Mn values, $5 \%$ of sulfate values, $4 \%$ of $\mathrm{Zn}$ values, $25 \%$ of Co values, $35 \%$ of $\mathrm{Ni}$ values, and $9 \%$ of $\mathrm{Cr}$ values. Samples were separated into surface water and groundwater and the root mean square error (RMSE) between the cumulative percentage and the cumulative percentage of the equivalent normal and lognormal distributions was calculated for each parameter. Mean values of RMSE averaged over all elements and compounds and over all on-site parameters $(\mathrm{pH}, \mathrm{EC}$, temperature) were also calculated. For surface water, element and compound distributions were a better fit to a lognormal distribution (mean RMSE $=8.8 \%$ ) than a normal distribution (mean RMSE $=19.6 \%$ ) for all chemical parameters (Figs. 3a-b). Although, on average, the distributions for on-site parameters for surface water were a better fit to a lognormal distribution (mean RMSE $=4.1 \%$ ) than a normal distribution (mean $\mathrm{RMSE}=5.8 \%$ ), the distribution for $\mathrm{pH}$ was a slightly better fit to a normal distribution ( $\mathrm{RMSE}=4.0 \%$ ) than a lognormal distribution (RMSE $=4.1 \%$ ) (Figs. 3c-d). For groundwater, element and compound distributions were also a better fit to a lognormal distribution (mean RMSE $=8.6 \%$ ) than a normal distribution (mean RMSE $=16.9 \%$ ) for all chemical parameters except $\mathrm{Cr}$ (Figs. 3e-f). Just as with surface water, although, on average, the distributions for on-site parameters for groundwater were a better fit to a lognormal distribution (mean $\mathrm{RMSE}=7.2 \%$ ) than a normal distribution (mean RMSE $=8.8 \%$ ), the distribution for $\mathrm{pH}$ was a slightly better fit to a normal distribution (RMSE $=3.4 \%$ ) than a lognormal distribution (RMSE $=3.5 \%$ ) (Figs. $3 \mathrm{~g}$-h). Based on the above, it was decided to carry out all statistics on the values of $\mathrm{pH}$ and on the logarithms of the values of EC, temperature, and element and compound concentrations, with all zero values set equal to the detection limit.

Competing models for As contamination were first tested using the complete data set of 33 surface water sites and 24 groundwater sites. The fluvial recharge model was tested by using the Student's t-test to compare the geometric mean concentrations for groundwater and surface water. The difference between the geometric mean As concentrations of surface water $(\mathrm{As}=0.009 \mathrm{mg} / \mathrm{L})$ and groundwater $(\mathrm{As}=0.036$ $\mathrm{mg} / \mathrm{L}$ ) was statistically significant at the $95 \%$ confidence level, which is inconsistent with the fluvial recharge model (Fig. 4a). Differences in concentrations of all other elements and compounds were indistinguishable, except for the statistically significant increase in concentration of $\mathrm{Cu}$ in groundwater 


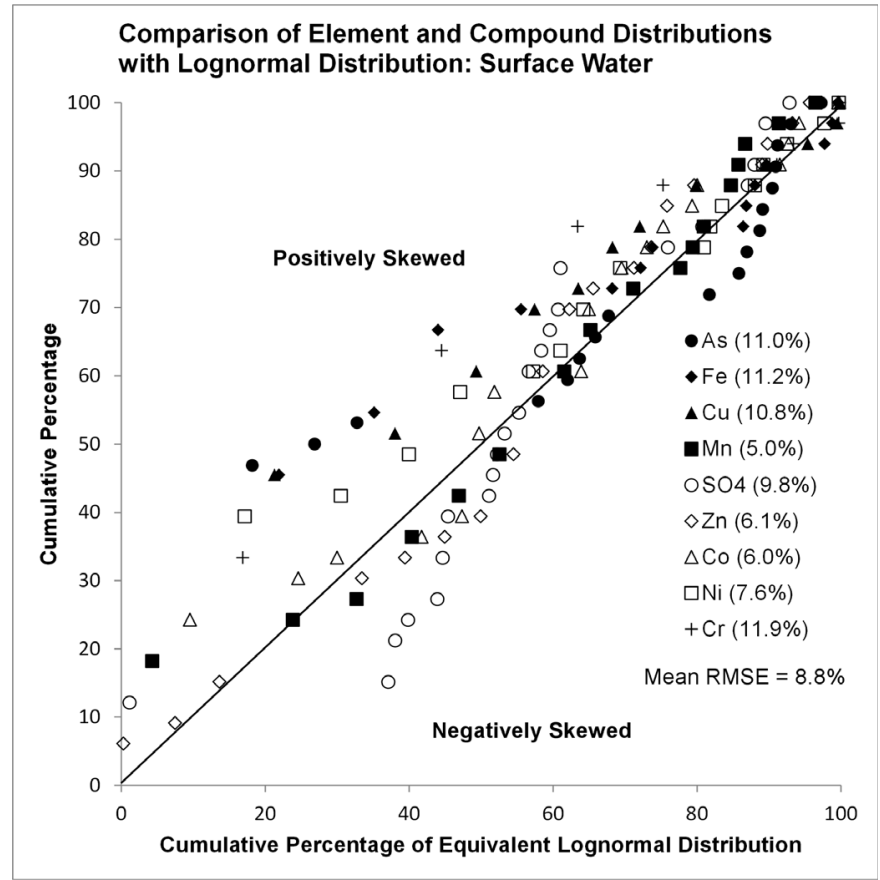

Fig. 3b: A comparison of the cumulative percentage of each element and compound in surface water with the equivalent lognormal distribution with the same mean and standard deviation showed element and compound distributions to be a better fit to a lognormal distribution. The root mean square error (RMSE) averaged over all parameters was $8.8 \%$ (RMSE for each parameter shown in parentheses).

$(\mathrm{Cu}=0.09 \mathrm{mg} / \mathrm{L})$ relative to surface water $(\mathrm{Cu}=0.03 \mathrm{mg} / \mathrm{L})$ (Fig. 4a). Differences in $\mathrm{pH}$ and $\mathrm{EC}$ were indistinguishable, although the elevation in surface water temperature $\left(17.7^{\circ} \mathrm{C}\right)$ relative to groundwater temperature $\left(15.0^{\circ} \mathrm{C}\right)$ was statistically significant at the $99 \%$ confidence level. In both surface water and groundwater, concentrations of $\mathrm{As}, \mathrm{Cu}, \mathrm{Mn}, \mathrm{Zn}, \mathrm{Co}, \mathrm{Ni}$ and $\mathrm{Cr}$ were elevated relative to global averages, while only surface water sulfate was elevated relative to its global average (Langmuir 1997) (Fig. 4a).

The reductive-dissolution and sulfide-oxidation models were tested using the complete data set by comparing the concentration of As in groundwater with concentrations of $\mathrm{Fe}$, $\mathrm{Mn}$ and sulfate. Arsenic was uncorrelated with $\mathrm{Fe}\left(\mathrm{R}^{2}=0.19\right)$, $\operatorname{Mn}\left(\mathrm{R}^{2}=3 \times 10^{-6}\right)$ and sulfate $\left(\mathrm{R}^{2}=0.05\right)$, which is inconsistent with both models. The reductive-dissolution model predicts a negative relation between As and sulfate due to the lack of sulfate under reducing conditions, while the sulfide-oxidation model predicts a positive relation between As and sulfate due to the abundance of sulfate that should result from the oxidation of sulfides and release of co-precipitated As. The sulfide-oxidation model predicts moreover a positive relation between As and between $\mathrm{Fe}$ or $\mathrm{Mn}$ or some other sulfideforming transition element. Consideration of other transition elements or various molar sums of the five transition elements most commonly associated with $\mathrm{As}(\mathrm{Fe}, \mathrm{Cu}, \mathrm{Ni}, \mathrm{Co}, \mathrm{Zn})$
(Boyle and Jonasson 1973) resulted in correlations no better than $\mathrm{R} 2=0.24$. Although an increase in $\mathrm{pH}$ should release As by decreasing the number of positively-charged sorption sites, $\mathrm{pH}$ was uncorrelated with As for both surface water (R2 $=0.15)$ and groundwater $(\mathrm{R} 2=0.20)$. The lack of correlation between $\mathrm{pH}$ and As makes it unlikely that elevated As results from the very alkaline environment (mean groundwater $\mathrm{pH}=$ 8.49 , mean surface water $\mathrm{pH}=8.59$ ) of Mustang Valley. In summary, the complete data set does not lend support for any of the existing models for As contamination of groundwater.

However, a very different story emerges when sampling sites are divided into two spatial clusters. The outside of the ellipse in Fig. 5 (called Region I) includes 37 sites (but only 36 As measurements) with geometric mean As $=0.071 \mathrm{mg} / \mathrm{L}$ and maximum As $=0.848 \mathrm{mg} / \mathrm{L}$. The inside of the ellipse (called Region II) includes 20 sites, of which 17 had undetectable As (Surface Water As Ranks 18, 20-32 and Groundwater As Ranks 22-24) with remaining measurements of $\mathrm{As}=0.001 \mathrm{mg} / \mathrm{L}$ (Groundwater As Rank 21), As $=0.002 \mathrm{mg} / \mathrm{L}$ (Surface Water As Rank 17) and As $=0.004 \mathrm{mg} / \mathrm{L}$ (Groundwater As Rank 20) (Tables 1a, 2a). (The shape of the ellipse in Fig. 5 has no significance aside from including the 20 sites named above.) When sites in Region I (high-As region) were considered separately, the geometric means of surface water As ( 0.056

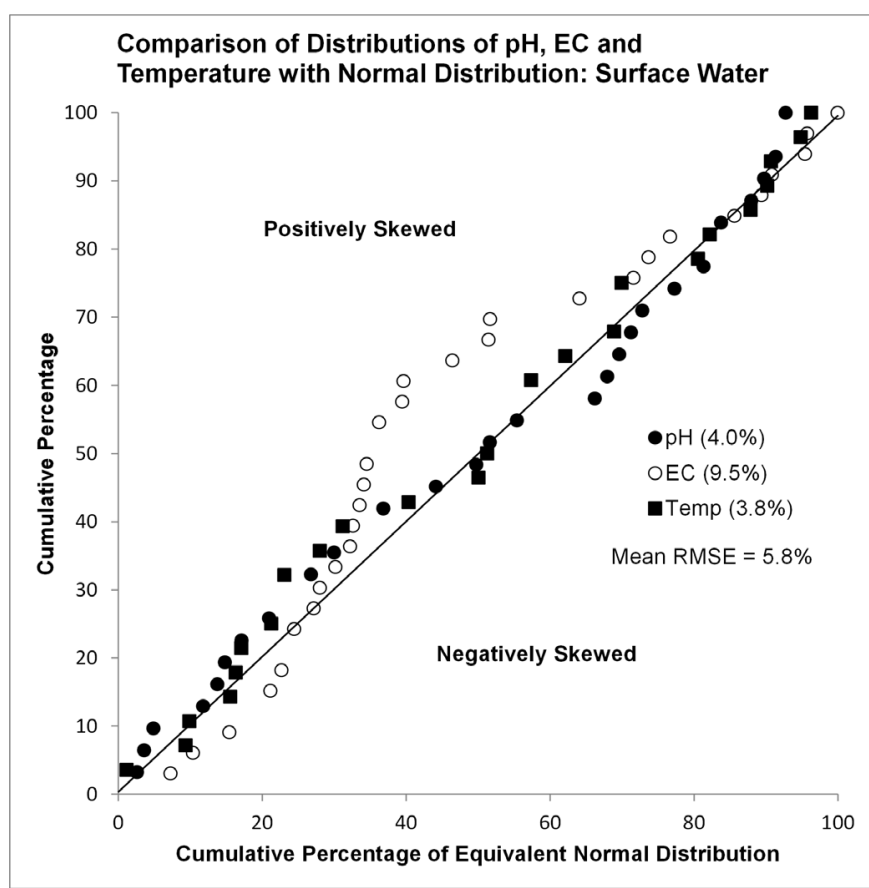

Fig. 3c: A comparison of the cumulative percentage of $\mathbf{p H}$, electrical conductivity (EC), and temperature in surface water with the equivalent normal distribution with the same mean and standard deviation showed distributions to be a good fit to a normal distribution. The root mean square error (RMSE) averaged over all parameters was $5.8 \%$ (RMSE for each parameter shown in parentheses). 
$\mathrm{mg} / \mathrm{L})$ and groundwater As $(0.087 \mathrm{mg} / \mathrm{L})$ were statistically indistinguishable (Fig. 4b). For all other chemical parameters, the only statistically significant differences were the increase in groundwater $\mathrm{Cu}(0.14 \mathrm{mg} / \mathrm{L})$ relative to surface water $\mathrm{Cu}$ $(0.03 \mathrm{mg} / \mathrm{L})$ and the elevation of surface water temperature $\left(18.3^{\circ} \mathrm{C}\right)$ over groundwater temperature $\left(14.8^{\circ} \mathrm{C}\right)$ at the $95 \%$ and $99 \%$ confidence levels, respectively (Fig. 4b). As in the combined data set, concentrations of groundwater and surface water $\mathrm{As}, \mathrm{Cu}, \mathrm{Mn}, \mathrm{Zn}, \mathrm{Co}, \mathrm{Ni}$ and $\mathrm{Cr}$ were elevated relative to global averages, while only surface water sulfate was elevated relative to its global average (Langmuir 1997) (Fig. 4b).

Similarly, when sites in Region II (low-As region) were considered separately, the geometric means of surface water As $(0.001 \mathrm{mg} / \mathrm{L})$ and groundwater As $(0.001 \mathrm{mg} / \mathrm{L})$ were statistically indistinguishable (Fig. 4c). For all other chemical parameters, the only statistically significant differences were the increases in surface water $\mathrm{Fe}(0.04 \mathrm{mg} / \mathrm{L})$ over groundwater $\mathrm{Fe}(0.01 \mathrm{mg} / \mathrm{L})$, surface water Co $(0.012 \mathrm{mg} / \mathrm{L})$ over groundwater Co $(0.002 \mathrm{mg} / \mathrm{L})$, and surface water $\mathrm{pH}$ (8.50) over groundwater $\mathrm{pH}(8.17)$ at the $95 \%, 99 \%$ and $95 \%$

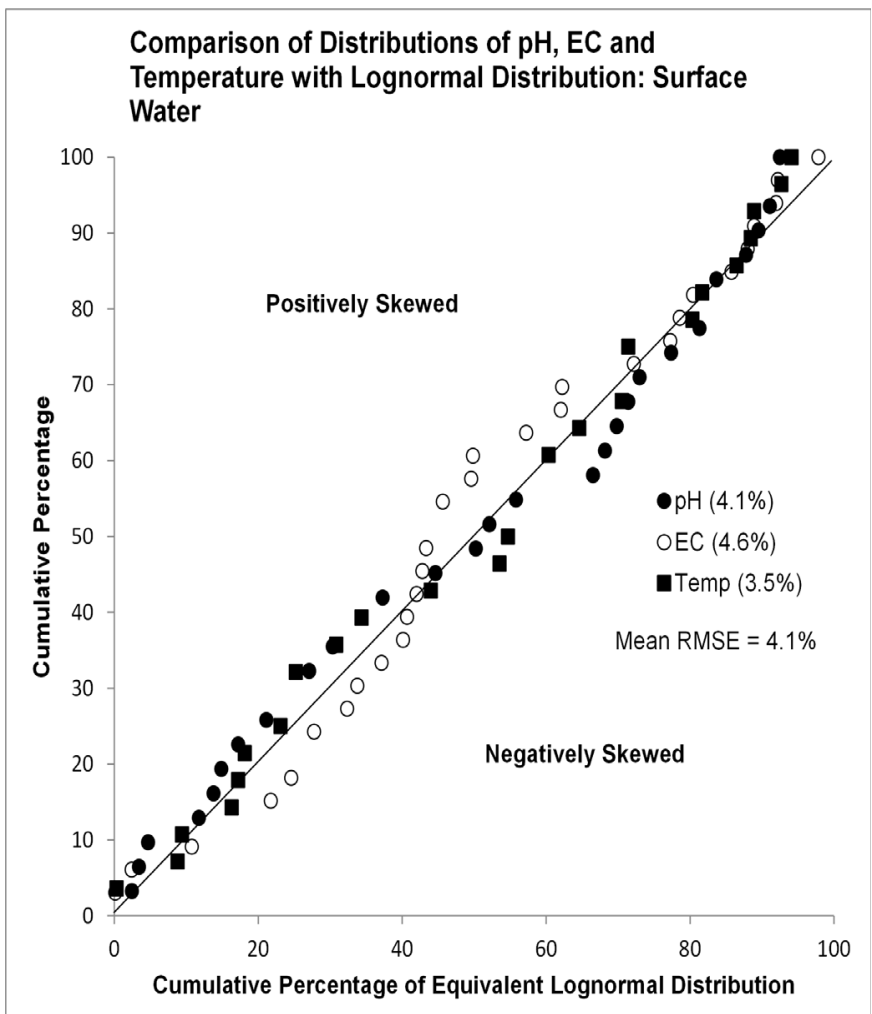

Fig. 3d: A comparison of the cumulative percentage of $\mathrm{pH}$, electrical conductivity (EC), and temperature in surface water with the equivalent lognormal distribution with the same mean and standard deviation showed distributions of EC and temperature to be a better fit to a lognormal distribution, while the distribution of pH was a better fit to a normal distribution. The root mean square error (RMSE) averaged over all parameters was $4.1 \%$ (RMSE for each parameter shown in parentheses). confidence levels, respectively (Fig. 4c). Concentrations of groundwater and surface water $\mathrm{Cu}, \mathrm{Mn}, \mathrm{Zn}, \mathrm{Co}, \mathrm{Ni}$ and $\mathrm{Cr}$ (but not As) were elevated relative to global averages, while only surface water sulfate was elevated relative to its global average (Langmuir 1997) (Fig. 4c). The separation of data into two spatial clusters does produce results consistent with the fluvial recharge model. The elevation of groundwater As over surface water As in the complete data set can now be seen as an artifact of the greater percentage of groundwater measurements in Region I (53\%) than Region II (25\%).

The reductive-dissolution and sulfide-oxidation models were also be re-examined by separating sampling sites into high- and low-As regions. Meaningful correlations with As could not be found in Region II as the range of As measurements was too small. Considering Region I alone did not improve correlations between groundwater As and $\mathrm{Fe}\left(\mathrm{R}^{2}\right.$ $=0.01), \mathrm{Mn}\left(\mathrm{R}^{2}=0.005\right)$, or any combination of the transition elements $\left(R^{2}<0.08\right)$, which is not consistent with either the reductive-dissolution or sulfide-oxidation models. The spatial separation of samples also did not improve correlations

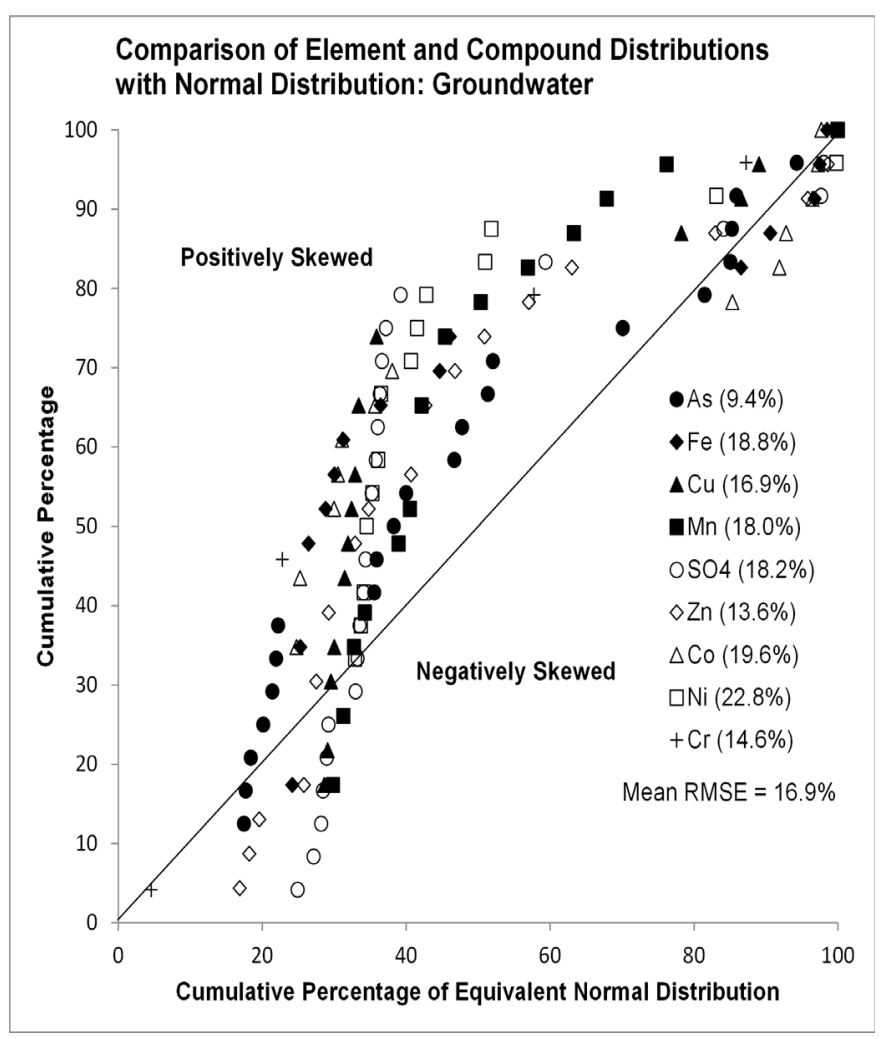

Fig. 3e: A comparison of the cumulative percentage of each element and compound in groundwater with the equivalent normal distribution with the same mean and standard deviation showed element and compound distributions to be a moderate fit to a normal distribution. The root mean square error (RMSE) averaged over all parameters was $16.9 \%$ (RMSE for each parameter shown in parentheses). 
between As and $\mathrm{pH}$ either for Region $\mathrm{I}\left(\mathrm{R}^{2}\right.$ for surface water $=$ $0.05, \mathrm{R}^{2}$ for groundwater $\left.=0.005\right)$ or Region II $\left(\mathrm{R}^{2}\right.$ for surface water $=0.005, \mathrm{R}^{2}$ for groundwater $=0.002$ ). However, in Region I, sulfate was weakly negatively correlated with As for surface water $\left(R^{2}=0.34, P=0.004\right)$, groundwater $\left(R^{2}=0.24\right.$, $\mathrm{P}=0.02)$, and combined groundwater and surface water $\left(\mathrm{R}^{2}=\right.$ $0.28, \mathrm{P}=0.0002$ ) (Fig. 6). The negative correlation between groundwater sulfate and As is consistent with the reductivedissolution model and inconsistent with the sulfide-oxidation model.

Region I was not only elevated with respect to Region II in both groundwater and surface water As, but statistically significant elevations were also found in groundwater $\mathrm{Fe}(0.08$ $\mathrm{mg} / \mathrm{L}$ vs. $0.01 \mathrm{mg} / \mathrm{L}$ ), combined (groundwater + surface water) $\mathrm{Cu}(0.07 \mathrm{mg} / \mathrm{L}$ vs. $0.03 \mathrm{mg} / \mathrm{L})$, groundwater $\mathrm{Cu}(0.14 \mathrm{mg} / \mathrm{L}$ vs. $0.02 \mathrm{mg} / \mathrm{L})$, combined $\mathrm{Zn}(0.14 \mathrm{mg} / \mathrm{L}$ vs. $0.08 \mathrm{mg} / \mathrm{L})$, groundwater Co $(0.013 \mathrm{mg} / \mathrm{L}$ vs. $0.002 \mathrm{mg} / \mathrm{L})$, combined $\mathrm{pH}$ (8.62 vs. 8.42$)$, groundwater $\mathrm{pH}$ (8.58 vs. 8.17$)$, and surface water $\mathrm{pH}(8.67$ vs. 8.50$)$ (Table 3$)$. The higher $\mathrm{pH}$ values in Region I are consistent with mobilization of As by reduction in the number of positively-charged sites, but the range of $\mathrm{pH}$ seems small for such a large difference in As concentrations. The higher concentrations of the transitions elements $\mathrm{Fe}, \mathrm{Cu}$,

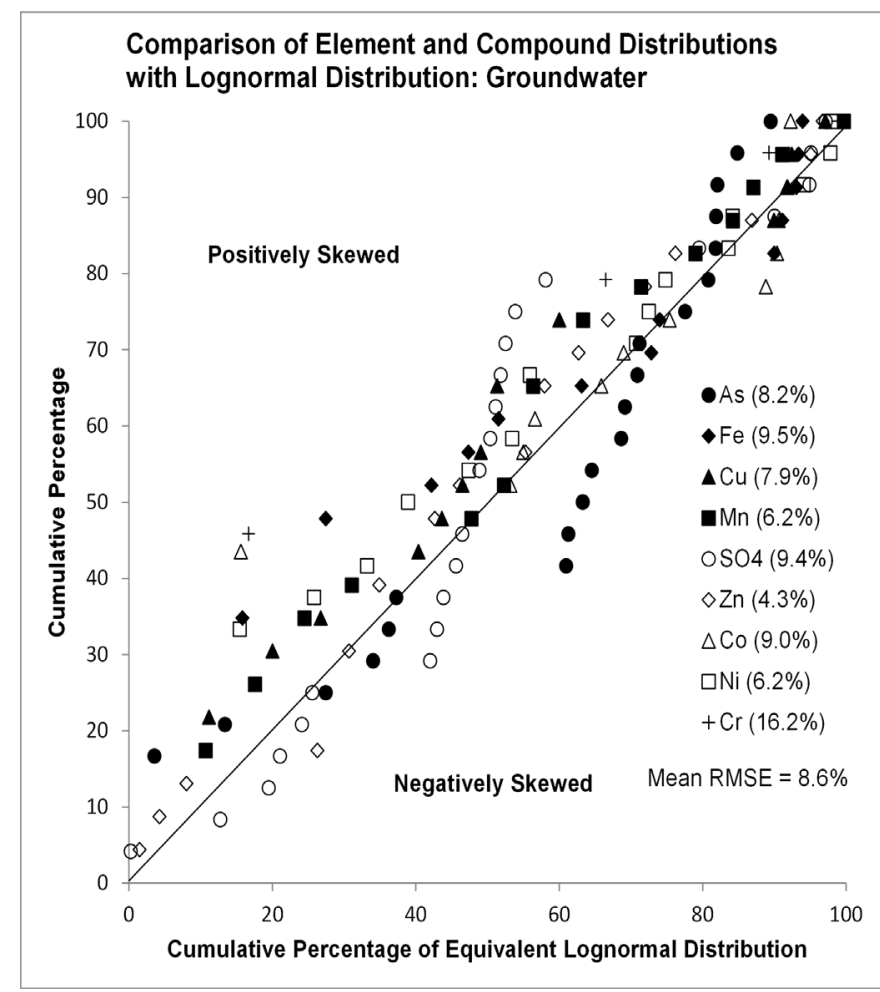

Fig. 3f: A comparison of the cumulative percentage of each element and compound in groundwater with the equivalent lognormal distribution with the same mean and standard deviation showed element and compound distributions to be a better fit to a lognormal distribution. The root mean square error (RMSE) averaged over all parameters was 8.6\% (RMSE for each parameter shown in parentheses).

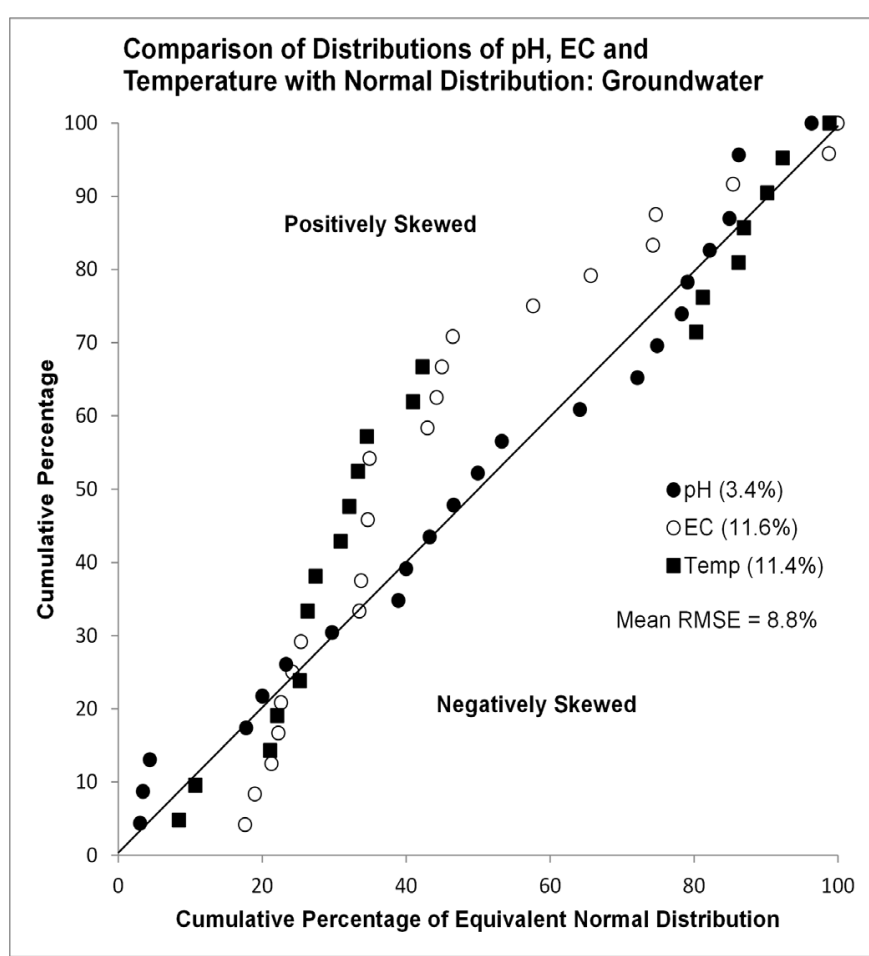

Fig. 3g: A comparison of the cumulative percentage of $\mathrm{pH}$, electrical conductivity (EC), and temperature in groundwater with the equivalent normal distribution with the same mean and standard deviation showed distributions to be a good fit to a normal distribution. The root mean square error (RMSE) averaged over all parameters was $8.8 \%$ (RMSE for each parameter shown in parentheses).

$\mathrm{Zn}$ and $\mathrm{Co}$ in Region I could argue in favor of the sulfideoxidation model. However, the lack of correlation between groundwater As and the transition elements in Region I offers no evidence in favor of subsurface sulfide oxidation. The regional association between As and the transition elements without site-by-site correlations (for either surface water or groundwater) suggests that sulfide minerals are being oxidized on the surface after which the As oxyanions and the various cations travel separate pathways in overland flow, which is fully consistent with the fluvial recharge model.

\section{DISCUSSION}

The obvious question is whether the residents of the village of Lo-Manthang display any of the ill effects of arsenicosis (hardening of the skin on the palms and soles, neurological disorders, and increased probability of stomach and bladder cancers). It is impossible to answer that question in the absence of any survey by health professionals. It is possible that the water taps were installed too recently for effects of chronic exposure to As to have appeared, as was argued for Pokhara Valley (Emerman et al. 2013). We were unable to locate any other water sources within Lo-Manthang besides the taps and the canal from Chhorak Dokpa Khola or to determine what water sources were used prior to installation 


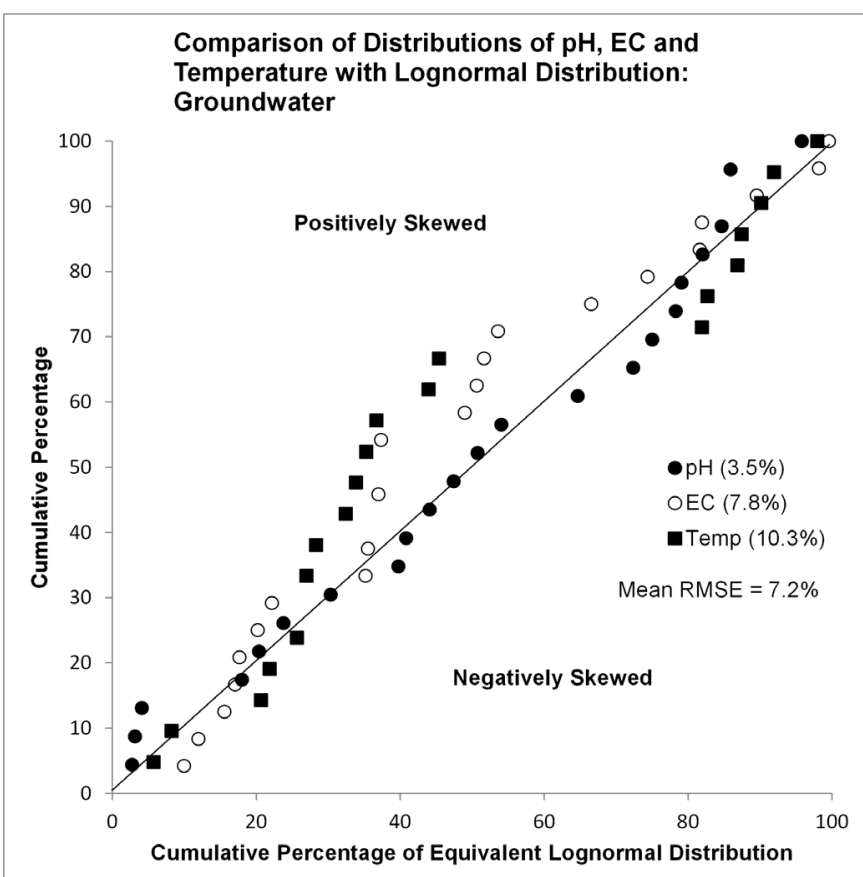

Fig. 3h: A comparison of the cumulative percentage of $\mathrm{pH}$, electrical conductivity (EC), and temperature in groundwater with the equivalent lognormal distribution with the same mean and standard deviation showed distributions of EC and temperature to be a better fit to a lognormal distribution, while the distribution of $\mathrm{pH}$ was a better fit to a normal distribution. The root mean square error (RMSE) averaged over all parameters was $7.2 \%$ (RMSE for each parameter shown in parentheses).

of the water taps. We are skeptical that there have never been any other water sources within Lo-Manthang, as Lo-Manthang is a medieval walled village (the wall was constructed in the early 15 th century) and the lack of a water source within the wall would give the village no ability to withstand a siege. The quality of the water supply in Lo-Manthang certainly requires further attention. In a similar way, Boselli et al (2005) found that water from public taps in eight villages in Mustang Valley had bacterial counts exceeding WHO standards, which could result from the lack of sewage systems and protection of taps from human and animal wastes.

There seems to be a clear correspondence between both surface water and groundwater As and the surface lithology in the watershed that is supplying water to the surface water and groundwater sites (Fig. 5). The 32 sampling sites in the northern portion of Region I (high-As region north of the ellipse in Fig. 5) all receive overland flow from the Mustang and Mugu Granites, while the 20 sampling sites within Region II (low-As region) do not receive overland flow from these exposed granitic bodies. The only exception is a sampling site (Surface Water Rank 20) with undetectable As within Region I on Naktang Khola above the confluence with Ghami Khola (Table 1a, Fig. 5). In general, relative As concentrations cannot be assigned to particular rock bodies without measurements as the ranges within each rock type are too large. The range in granites is $0.2-15 \mathrm{mg} / \mathrm{kg}$, while the ranges in sandstones and non-marine shales (as would be found within the Tibetan Sedimentary Sequence) are 0.6-120 and 3.0-12 mg/kg, respectively (Smedley and Kinniburgh 2002). Although Sr, $\mathrm{Nd}, \mathrm{Pb}$ and $\mathrm{O}$ isotopes and rare earth elements have been measured in the Mustang and Mugu Granites, there have been no measurements of As or the transition elements (Vidal et al. 1984; Guillot et al. 1994; Le Fort and France-Lanord 1994, 1995; Harrison et al. 1997; Hurtado et al. 2002). Arsenic and the transition elements have also not been measured in the Tibetan Sedimentary Sequence (but see analysis of pebbles by Dürr and Gibling (1994)), nor, to the best of our knowledge, have As concentrations been measured in any rocks in Nepal. There is certainly room for further research in this area. One of the few cases in which different rock types have distinctive relative As concentrations is that much higher As concentrations tend to be found in the low-grade metamorphic rocks phyllite and slate (mean $=18 \mathrm{mg} / \mathrm{kg}$, range $0.5-143 \mathrm{mg} / \mathrm{kg}$ ) than the high-grade metamorphic rocks schist and gneiss (mean $=1.1 \mathrm{mg} / \mathrm{kg}$, range $<0.1-18.5 \mathrm{mg} / \mathrm{kg}$ ) (Smedley and Kinniburgh 2002; Emerman et al. 2007). Emerman et al. (2013) found in Pokhara Valley

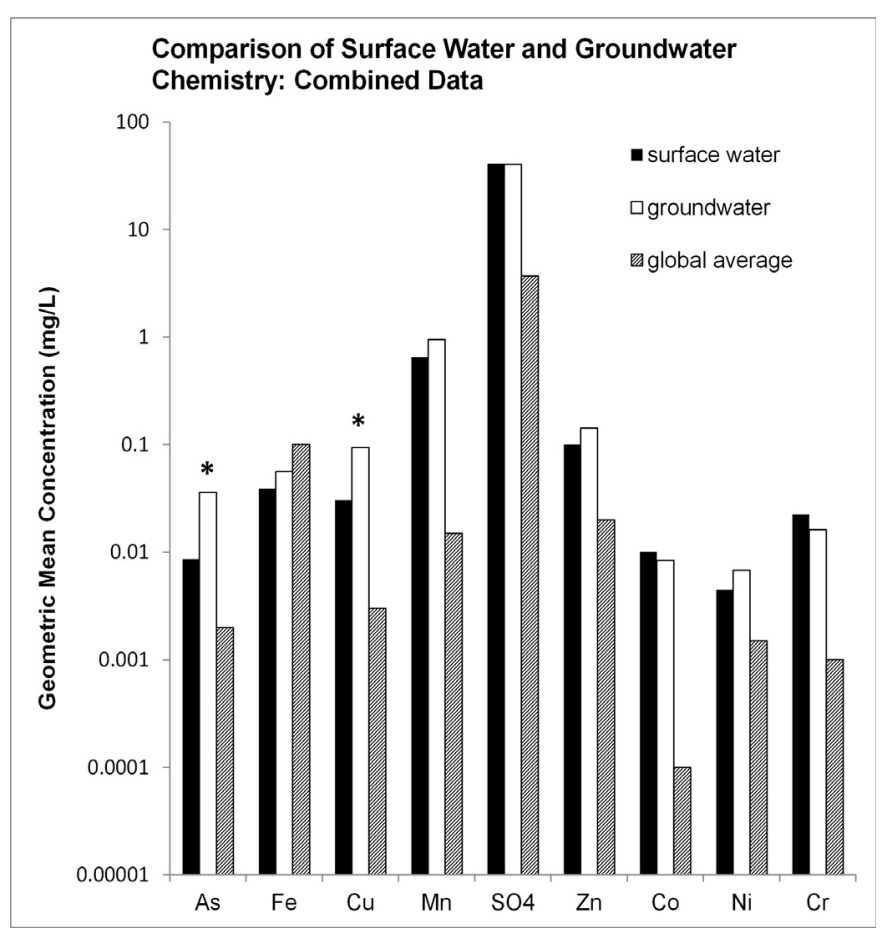

Fig. 4a: The symbol * indicates differences between geometric mean concentrations in surface water and groundwater are statistically significant at the $\mathbf{9 5 \%}$ confidence level according to the Student's t-test. For the combined data set, the increases in concentration of $\mathrm{As}$ and $\mathrm{Cu}$ in groundwater relative to surface water are statistically significant. In both surface water and groundwater, concentrations of $\mathrm{As}, \mathrm{Cu}, \mathrm{Mn}, \mathrm{Zn}, \mathrm{Co}, \mathrm{Ni}$ and $\mathrm{Cr}$ were elevated relative to global averages, while only surface water sulfate was elevated relative to its global average. The global average shown for sulfate applies only to surface water as the groundwater global average is considerably higher $\left(\mathrm{SO}_{4}^{-2}=\right.$ $30 \mathrm{mg} / \mathrm{L}$ ) (Langmuir 1997). 
that rivers draining phyllites of the Kuncha Formation (Lesser Himalayan Zone) had much higher As concentrations than rivers draining the Himalayan Gneiss (Higher Himalayan Zone), which was consistent with the finding by Emerman et al. (2007) of low fluvial As throughout the Higher Himalayan Zone. However, in Pokhara Valley, it was not possible to compare groundwater As with watershed surface lithology as there were no wells or springs in the watershed draining the Himalayan Gneiss. To the best of our knowledge, the present study is the first study that has connected groundwater As with watershed surface lithology, as opposed to subsurface lithology and environmental conditions. This connection is the strongest evidence in favor of the fluvial recharge model for As contamination of groundwater.

The exception to the above correspondence between surface lithology and surface water and groundwater As is the five sampling sites in Region I south of the ellipse (Surface

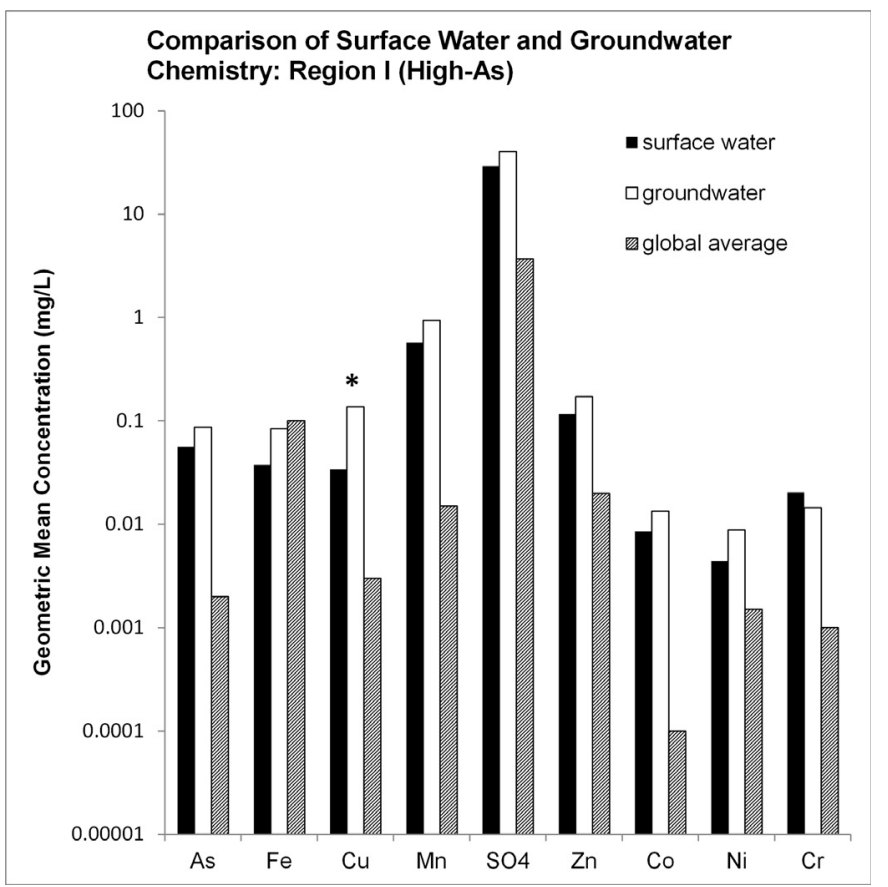

Fig. 4b: The symbol * indicates differences between geometric mean concentrations in surface water and groundwater are statistically significant at the $\mathbf{9 5 \%}$ confidence level according to the Student's t-test. For Region I (high-As region), the difference between concentration of As in surface water and groundwater is not statistically significant, while the increase in concentration of $\mathrm{Cu}$ in groundwater relative to surface water is statistically significant. In both surface water and groundwater, concentrations of $\mathrm{As}, \mathrm{Cu}, \mathrm{Mn}, \mathrm{Zn}, \mathrm{Co}, \mathrm{Ni}$ and $\mathrm{Cr}$ were elevated relative to global averages, while only surface water sulfate was elevated relative to its global average. The global average shown for sulfate applies only to surface water as the groundwater global average is considerably higher $\left(\mathrm{SO}_{4}^{-2}=30 \mathrm{mg} / \mathrm{L}\right)$ (Langmuir 1997).
Water As Ranks 6, 10, and 16 and Groundwater As Ranks 14 and 16) (Tables 1a, 2a, Figs. 2, 5). All of these sites are found within the Marpha Formation, which is the only formation in the Thakkhola Graben fill that is dominated by mudstones (Adhikari and Wagreich 2011b). On that basis, it is possible that As mobilization by reductive dissolution is occurring in this area. However, with only two groundwater measurements, it is impossible to carry out the statistics that would support this model.

The negative correlation between As and sulfate for both surface water and groundwater for all of Region I could support the reductive-dissolution model, but that is unlikely given the paucity of fine-grained sedimentary rocks in the Thakkhola Graben fill outside of the Marpha Formation (Adhikari and Wagreich 2011b). Another possible explanation for the negative correlation is a competition for positively-charged sorption sites between the sulfate and the arsenate oxyanions.

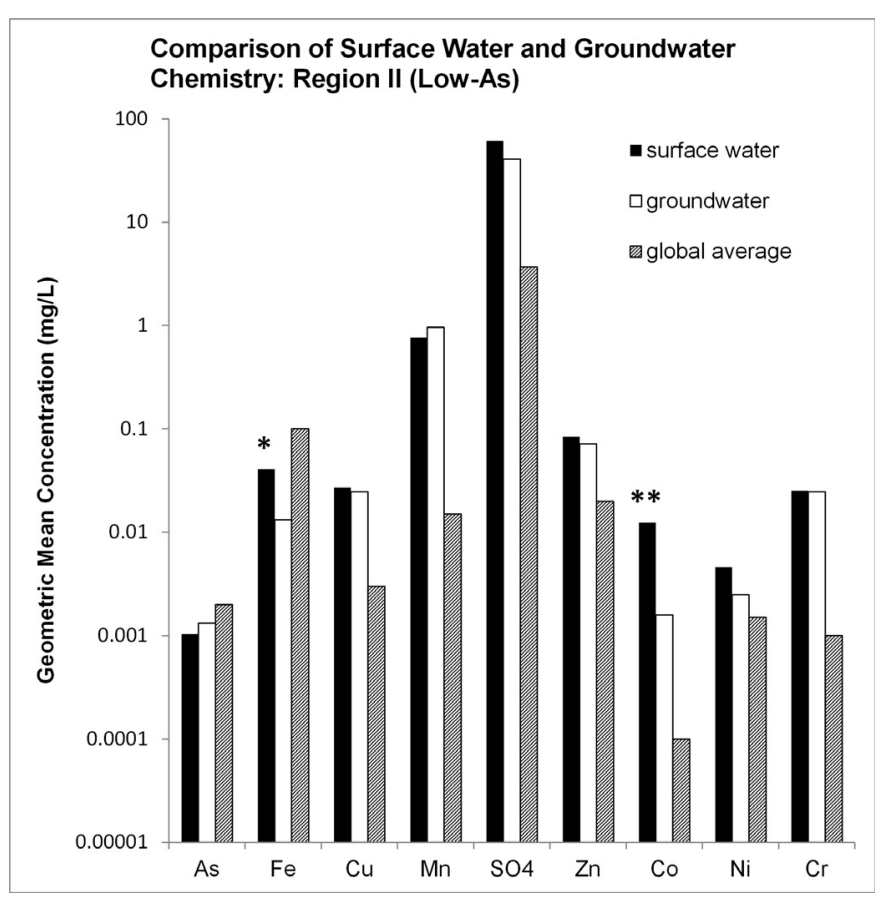

Fig. 4c: The symbols * and ** indicate differences between geometric mean concentrations in surface water and groundwater are statistically significant at the $95 \%$ and $99 \%$ confidence levels, respectively, according to the Student's t-test. For Region II (lowAs region), the difference between concentration of As in surface water and groundwater is not statistically significant, while the increases in concentration of $\mathrm{Fe}$ and $\mathrm{Co}$ in surface water relative to groundwater are statistically significant. In both surface water and groundwater, concentrations of $\mathrm{Cu}, \mathrm{Mn}, \mathrm{Zn}, \mathrm{Co}, \mathrm{Ni}$ and $\mathrm{Cr}$ were elevated relative to global averages, while only surface water sulfate was elevated relative to its global average. The global average shown for sulfate applies only to surface water as the groundwater global average is considerably higher $\left(\mathrm{SO}_{4}^{-2}=30\right.$ mg/L) (Langmuir 1997). 
Table 3: Statistically Significant Differences between Geochemistry of Regions I and II

\begin{tabular}{|c|c|c|c|c|c|c|}
\hline \multicolumn{5}{|c|}{ Region I (high As) } & \multicolumn{3}{c|}{ Region II (low As) } \\
\hline & Total & Subsurface & Surface & Total & Subsurface & Surface \\
\hline $\mathrm{As}(\mathrm{mg} / \mathrm{L})^{\mathrm{a}}$ & 0.071 & 0.087 & 0.056 & $0.001^{* * *}$ & $0.001^{* * *}$ & $0.001^{* * *}$ \\
$\mathrm{Fe}(\mathrm{mg} / \mathrm{L})$ & 0.06 & 0.08 & 0.04 & 0.03 & $0.01^{* *}$ & 0.04 \\
$\mathrm{Cu}(\mathrm{mg} / \mathrm{L})$ & 0.07 & 0.14 & 0.03 & $0.03^{*}$ & $0.02^{*}$ & 0.03 \\
$\mathrm{Zn}(\mathrm{mg} / \mathrm{L})$ & 0.14 & 0.17 & 0.12 & $0.08^{*}$ & 0.07 & 0.08 \\
$\mathrm{Co}(\mathrm{mg} / \mathrm{L})$ & 0.011 & 0.013 & 0.009 & 0.007 & $0.002^{* *}$ & 0.012 \\
$\mathrm{pH}$ & 8.62 & 8.58 & 8.67 & $8.42^{*}$ & $8.17^{*}$ & $8.50^{*}$ \\
\hline
\end{tabular}

aValues are geometric means for elemental concentrations and arithmetic mean for $\mathrm{pH}$.

${ }^{*, * * * *}$ indicates differences between values for Region I and II are statistically significant at the $95 \%, 99 \%$, and $99.9 \%$ confidence intervals.

However, in laboratory experiments, Genc and Tjell (2003) and Manna et al. (2003) found weak competition from sulfate for sorption sites, while Frau et al. (2010) found significant competition at sulfate concentration $0.1 \mathrm{M}(9606 \mathrm{mg} / \mathrm{L})$, but not $0.01 \mathrm{M}(961 \mathrm{mg} / \mathrm{L})$. As the geometric mean sulfate concentration in Region I was 35 $\mathrm{mg} / \mathrm{L}$, significant sulfate-arsenate competition would not be expected based on the laboratory experiments. Sulfate-arsenate competition has not been reported in field studies, although the possibility deserves further study.

\section{CONCLUSIONS}

The results of this study are consistent with the fluvial recharge model for As contamination of groundwater in the following ways:

1) There is a correspondence between surface water and groundwater As and the surface lithology of the headwaters that are supplying water to the sampling sites.

2) Fluvial As concentrations are statistically indistinguishable from groundwater As concentrations when sampling sites are separated into low-As and high-As spatial clusters, which correspond to watershed surface lithologies.

3) Fluvial As is uncorrelated with $\mathrm{pH}$, which is consistent with a lack of As sorption / desorption in overland flow or streambeds.

4) Groundwater $\mathrm{As}$ is uncorrelated with $\mathrm{pH}$ or any of the transition elements either individually or in combination, which is consistent with a lack of reductive dissolution, sulfide oxidation or any other groundwater As chemistry.

If As mobilization is a consequence of rapid erosion and if this rapid erosion is caused by the anthropogenic activities of deforestation

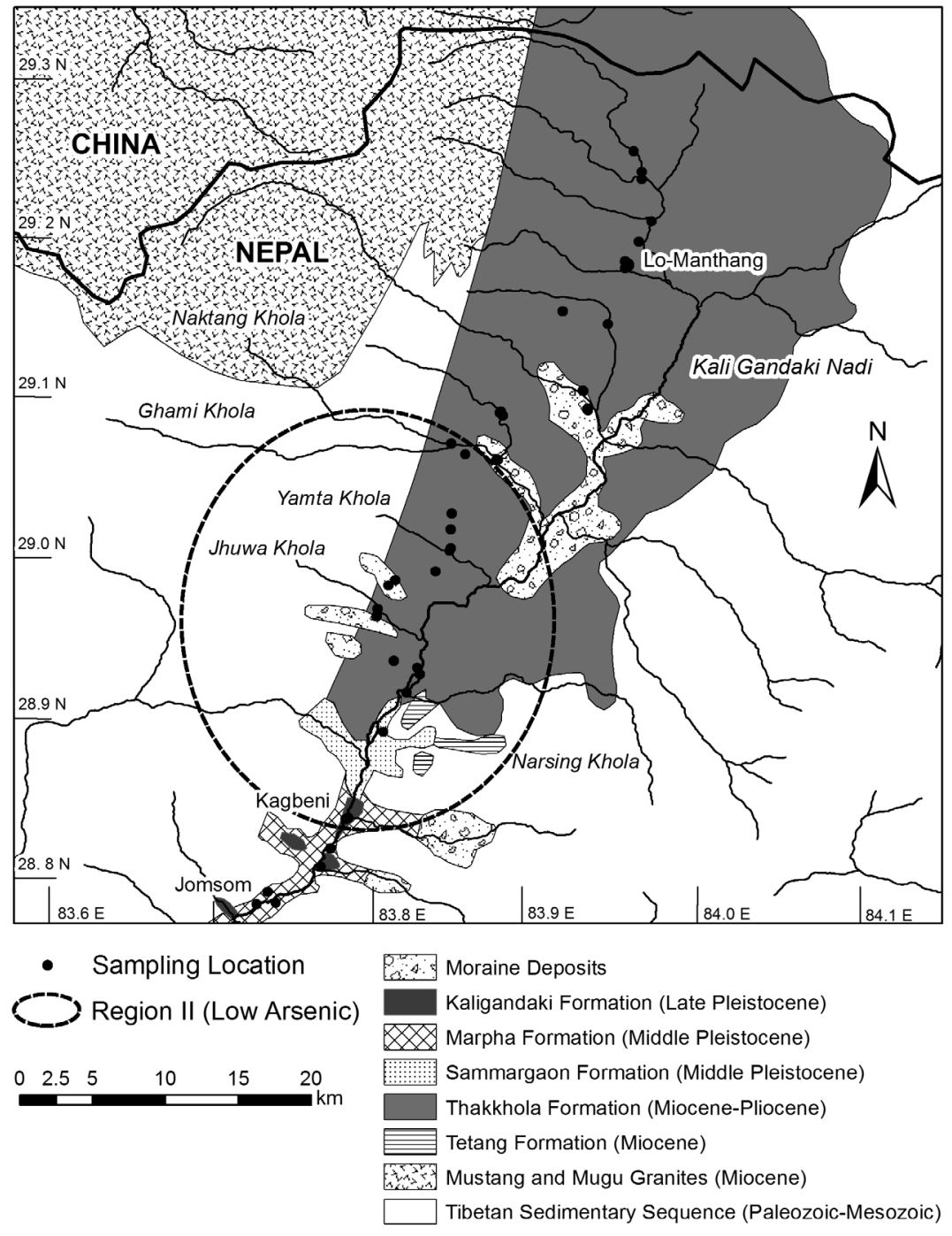

Fig. 5: Region I (outside of the ellipse) includes 37 sampling locations with geometric mean As $=0.071 \mathrm{mg} / \mathrm{L}$ and maximum $\mathrm{As}=0.87 \mathrm{mg} / \mathrm{L}$. Within Region II (inside of the ellipse) are 20 sampling locations, 17 of which had undetectable As with maximum As $=0.004 \mathrm{mg} / \mathrm{L}$. Locations within Region I receive surface runoff from the Mustang and Mugu Granites or are found within the Marpha Formation (south of Region II). Geologic map was redrawn from Hurtado et al. (2001) and Adhikari and Wagreich (2011). 
and overgrazing, then it is possible that the root causes of As contamination of groundwater in the tectonic valleys of Nepal cannot be addressed without also addressing the problem of land degradation. If deforestation were addressed for the purpose of slowing the rate of input of As into surface water and groundwater, then the priorities would need to be those areas whose surface lithology has an elevated As concentration. These priorities cannot be set without measurements of As concentrations of rock bodies in Nepal, so that this research is urgently needed. (See Emerman et al. (2012) for further thoughts along these lines.)

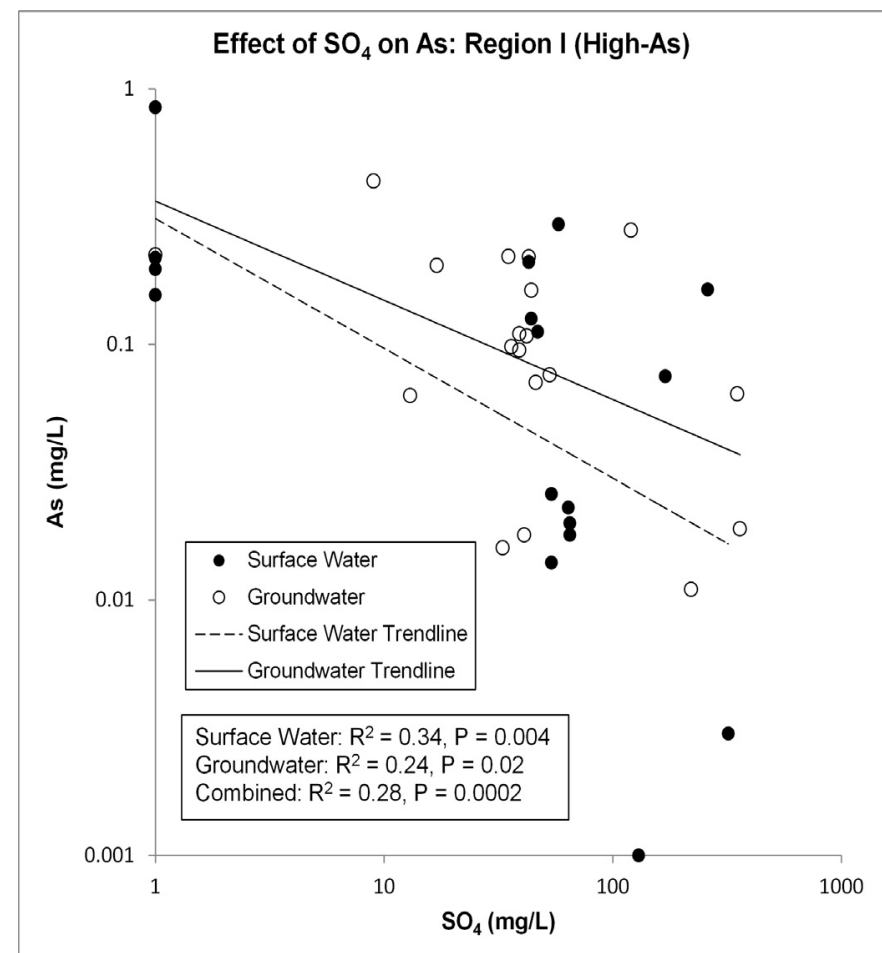

Fig. 6: Within Region I (high-As region) As was negatively correlated with sulfate, which is inconsistent with a model of subsurface sulfide oxidation, but consistent with either reductive dissolution or competition by sulfate for positively-charged sorption sites.

It is possible that As mobilization as a consequence of rapid erosion in Nepal is due almost entirely to the natural causes of climate and tectonic activity. This possibility could be addressed by measuring surface water and groundwater As in paired forested and deforested watersheds or paired overgrazed and properly managed watersheds. Such an investigation would be problematic in Nepal as so much of the country has already been deforested. Further investigations along these lines will be carried out in Bhutan where $72 \%$ of the total geographic area is still under forest cover (WCD 2010).

\section{ACKNOWLEDGEMENTS}

This research was partially funded by the Center for Engaged Learning (UVU), a Presidential Faculty Scholarly Activities Award (UVU), the Department of Earth Science (UVU), the Institute for Professional Engagement (UVU), a
Student Scholarly and Creative Opportunities Program (SCOP) Award (UVU), and a Student Scholarly Activities Committee (SAC) Award (College of Science and Health, UVU). We thank Michael P. Bunds for assistance in the field.

\section{REFERENCES}

Adhikari, B. R. and Wagreich, M., 2011a, Provenance evolution of collapse graben fill in the Himalaya-The Miocene to Quaternary Thakkhola-Mustang Graben (Nepal). Sediment. Geol., v. 233, pp. 1-14.

Adhikari, B. R. and Wagreich, M., 2011b, Facies analysis and basin architecture of the Thakkhola-Mustang Graben (Neogene-Quaternary), Central Nepal Himalaya. Austrian J. Earth Sci., v. 104, pp. 66-80.

Ahmad, S. A., Maharjan, M., Watanabe, C., and Ohtsuka, R., 2004, Arsenicosis in two villages in Terai lowland Nepal. Environ. Sci., v. 11, pp. 179-188.

Baade, J., Lang, A., Maeusbacher, R., and Wagner, G. A., 1998, Quaternary lake deposits in the Thakkhola Graben, Mustang, Nepal. Geol. Bull. Univ. Peshawar, v. 31, pp. 22-23.

Badal, K. M., Roy Choudhury, T., Samanta, G., Basu, G. K., Chowdury, P. P., Chanda, C. R., Lodh, D., Karan, N. K., Dhar, R. K., Tamili, D. K., Das, D., Saha, K. C., and Chakraborti, D., 1996, Arsenic in groundwater in seven districts of West Bengal, India - The biggest As calamity in the world. Current Sci., v. 70, pp. 976-985.

Bajracharya, A. M., Yami, K. D., Prasai, T., Basnyat, S. R., Lekhak, B., 2007, Assessment of drinking water quality of Kathmandu metropolitan areas. Nepal J. Sci. Technol., v. 8, pp. 113-118.

Bhattacharaya, P., Chatterjee, D. and Jacks, G., 1997, Occurrence of As-contaminated groundwater in alluvial aquifers from the Delta Plains, Eastern India: Options for safe drinking water supply. Water Resour. Dev., v. 13, pp. 79-92.

Bhattacharya, P., Tandukar, N., Neku, A., Valero, A. A., Mukherjee, A. B., and Jacks, G., 2003, Geogenic arsenic in groundwaters from Terai Alluvial Plain of Nepal. J. Phys. IV France, v. 107, pp. 173-176.

Bloom, A. L., 1998, Geomorphology: A Systematic Analysis of Late Cenozoic Landforms, 3rd ed., Prentice-Hall, Upper Saddle River, New Jersey, $482 \mathrm{p}$.

Bose, P. and Sharma, A., 2002, Role of iron in controlling speciation and mobilization of arsenic in subsurface environment. Water Res., v. 36, pp. 4916-4926.

Boselli, A. M., Caravello, G. U., and Baroni, A., 2005, The Upper Mustang (Nepal) ecosystem: Population, water quality and tourism. Aquat. Ecosyst. Health, v. 8, pp. 285-291.

Boyle, R. W., and Jonasson, I. R., 1973, The geochemistry of arsenic and its use as an indicator element in geochemical prospecting. J. Geochem. Explor., v. 2, pp. 251-296.

Brikowski, T. H., Smith, L. S., Shei, T.-C., and Shrestha, S. D., 2004, Correlation of electrical resistivity and arsenic contamination, Nawalparasi, Nepal. J. Nepal Geol. Soc., v. 30, pp. 99-106. 
Brikowski, T. H., Smith, L. S. S., and Shrestha, S. D., 2005, Electrical resistivity profiling to delineate low groundwater arsenic target zones in the Terai, Nawalparasi, Nepal. Abstracts with Programs - Geol. Soc. Amer., v. 37, p. 375.

Brikowski, T. H., Leybourne, M. I., Shrestha, S. D., Bhattacharya, P., Neku, A., and Smith, L., 2006, Geochemical indicators of groundwater arsenic mobilization mechanisms in the Ganges floodplain of Nepal. Abstracts with Programs - Geol. Soc. Amer., South-Central Sec., v. 38, p. 8.

Chamlagain, D. and Hayashi, D., 2006, Numerical modeling of graben faults with special reference to Thakkhola half graben, central Nepal Himalaya. J. Himal. Geol., v. 27, pp. 95-110.

Chapagain, S. K., Shrestha, S., Nakamura, T., Pandey, V. P., and Kazama, F., 2009, Arsenic occurrence in groundwater of Kathmandu Valley, Nepal. Desalination Water Treatment, v. 4, pp. 248-254.

Charlet, L. and Polya, A., 2006, Arsenic in shallow, reducing groundwaters in southern Asia: An environmental health disaster. Elements, v. 2, pp. 91-96.

Chhetri, P. B., 2006, Sustaining agriculture in Upper Mustang: Challenges and opportunities. J. Sustain. Agr., v. 27, pp. 109-124.

Colchen, M., Fort, M., and Freytet, P., 1980, Evolution paleogeographique et structurale du fosse de la Thakkhola-Mustang (Himalaya du Nepal), implications sur l'histoire recente de la chaine himalayenne. C. R. Acad. Sci. D. Nat., v. 290, pp. 311-314.

Colchen, M., 1998, The Thakkhola-Mustang Graben (Nepal) and the late Cenozoic extension of the Himalaya. Geol. Bull. Univ. Peshawar, v. 31, pp. 44-45.

Colchen, M., 1999, The Thakkhola-Mustang Graben in Nepal and the late Cenozoic extension in the Higher Himalayas. J. Asian Earth Sci., v. 17, pp. 683-702.

Dahal, B. M., Fuerhacker, M., Mentler, A., Karki, K. B., Shrestha, R. R., and Blum, W. E. H., 2008, Arsenic contamination of soils and agricultural plants through irrigation water in Nepal. Environ. Pollut., v. 155, pp. 157-163.

Dhar, R. K., Biswas, B. K., Samanta, G., Mandal, B. K., Chakraborti, D., Roy, S., Jafar, A., Islam, A., Ara, G., Kabir, S., Khan, A. W., Ahmed, S. K., and Hadi, S. A., 1997, Groundwater As calamity in Bangladesh. Current Sci., v. 73, pp. 48-59.

Dürr, S. B. and Gibling, M. R., 1994, Early Cretaceous volcaniclastic and quartzose sandstones from north central Nepal; composition, sedimentology and geotectonic significance. Geol. Rundsch., v. 83, pp. 6275.

Emerman, S. H., 2004, Deforestation, arsenic, and the selforganizing jungle in the Terai region of Nepal. J. Nepal Geol. Soc., v. 29, pp. 13-22.

Emerman, S. H., 2005, Arsenic and other heavy metals in the rivers of central Nepal. J. Nepal Geol. Soc., v. 31, pp. $11-18$.
Emerman, S. H., Bhattarai, T. N., Adhikari, D. P., Joshi, S. R., Lakhe, S. L., Luhrs, A. J., Prasai, K. R., and Robson, K. L., 2007, Origin of arsenic and other heavy metals in the rivers of Nepal. J. Nepal Geol. Soc., v. 35, pp. 29-36.

Emerman, S. H., Prasai, T., Anderson, R. B., and Palmer, M. A., 2010, Arsenic contamination of groundwater in the Kathmandu Valley, Nepal, as a consequence of rapid erosion. J. Nepal Geol. Soc., v. 40, pp. 49-60.

Emerman, S. H., Anderson, R. B., Bhandari, S., Bhattarai, R. R., Palmer, M. A., Bhattarai, T. N., and Bunds, M. P., 2011, Arsenic and other heavy metals in the Sunkoshi and Saptakoshi Rivers, eastern Nepal. J. Nepal Geol. Soc., v. 43, pp. 101-114.

Emerman, S. H., Luhrs, A. J., Sandford, S. E. and Finken, A., 2012, Self-organizing systems and environmental justice: Application to arsenic contamination of groundwater in Nepal, In: Emerman, S. H., Bjørnerud, M., Schneiderman, J. S., and Levy, S. A. (Eds.) Liberation Science: Putting Science to Work for Social and Environmental Justice, Lulu Press, Raleigh, North Carolina.

Emerman, S. H., Stuart, K. L., Sapkota, A., Khatri, S., Adhikari, B. R., Williams, J. A., and Garcia, P. K., 2013, Support for the fluvial recharge model for arsenic contamination of groundwater in Pokhara Valley, Nepal Himalaya. J. Nepal Geol. Soc., v. 46, pp. 75-94.

ENPHO (Environment and Public Health Organization) and USGS (United States Geological Survey), 2004, The state of arsenic 2003 in Nepal (a draft report). National Arsenic Steering Committee (NASC), Kathmandu, Nepal, $102 \mathrm{p}$.

Fort, M., 1985, Contribution of sedimentary and geomorphic data to the knowledge of paleoclimates in the Nepal Himalayas, In: Agrawal, D. P., Kusumgar, S., and Krishnamurthy, R. V. (Eds.) Climate and Geology of Kashmir, the Last 4 Million Years; Proceedings of the International Workshop on the Late Cenozoic Palaeoclimatic Changes in Kashmir and Central Asia, Today and Tomorrows Printers, New Delhi, India, pp. 159-189.

Fort, M., 1987, Geomorphic and hazards mapping in the dry, continental Himalaya; 1:50,000 maps of the Mustang District, Nepal. Mt. Res. Dev., v. 7, pp. 222-238.

Fort, M., 2010, Hillslope-channel coupling in the Nepal Himalayas and threat to man-made structures; the middle Kali Gandaki Valley. Geomorphology, v. 124, pp. 178199.

Fort, M. and Gupta, V. J., 1981, Plio-Pleistocene midlands Himalayan basins of Kathmandu, Pokhara and Kashmir, In: Krishnaswarmy, V. S., (Ed.) Field Conference, Neogene/Quaternary Boundary, IUGS, Paris, France, p. 6.

Fort, M., Bassoullet, J. P., Colchen, M., and Freytet, P., 1981, Sedimentological and structural evolution of the Thakkhola-Mustang Graben (Nepal Himalaya) during the late Neogene and Pleistocene, In: Sastry, M. V. A., Kurien, T. K., Dutta, A. K., and Biswas, S., (Eds.) Field Conference; Neogene-Quaternary Boundary, India, 
1979; Proceedings, Geological Survey of India, Calcutta, India, pp. 25-35.

Fort, M. and Freytet, P., 1982, The Quaternary sedimentary evolution of the intra-montane basin of Pokhara in relation to the Himalaya midlands and their hinterland (west central Nepal), In: Sinha, A. K., (Ed.) Contemporary Geoscientific Researches in Himalaya, v. 2, Bishen Singh Mahendra Pal Sigh, Dehra Dun, India, pp. 91-96.

Fort, M., Freytet, P., and Colchen, M., 1982, Structural and sedimentological evolution of the Thakkhola Graben (Nepal Himalayas). Z. Geomorphol. Supp., v. 42, pp. 7598.

France-Lanord, C., Gabens, O., Le Fort, P., and Gajurel, A. P., 1994, Major ion chemistry and H, O, C \& Sr isotope compositions in river water from Mustang and central Nepal; weathering in the Himalaya. J. Nepal Geol. Soc., v. 10 , pp. 45-46.

Frau, F., Addari, D., Atzei, D., Biddau, R., Cidu, R., and Rossi, A., 2010, Influence of major ions on $\mathrm{As}(\mathrm{V})$ adsorption by synthetic 2-line ferrihydrite; kinetic investigation and XPS study of the competitive effect of bicarbonate. Water Air Soil Poll., v. 205, pp. 25-41.

Garzione, C. N., Quade, J., DeCelles, P. G., and English, N. B., 2000a, Predicting paleoelevation of Tibet and the Himalaya from $\delta^{18} \mathrm{O}$ vs. altitude gradients in meteoric water across the Nepal Himalaya. Earth Planet. Sc. Lett., v. 183 , pp. $215-229$.

Garzione, C. N., Dettman, D. L., Quade, J., DeCelles, P. G., and Butler, R. F., 2000b, High times on the Tibetan Plateau; paleoelevation of the Thakkhola Graben, Nepal. Geology, v. 28, pp. 339-342.

Garzione, C. N., DeCelles, P. G., Hodkinson, D. G., Ojha, T. P., and Upreti, B. N., 2003, East-west extension and Miocene environmental change in the southern Tibetan Plateau; Thakkhola Graben, central Nepal. Geol. Soc. Am. Bull., v. 115, pp. 3-20.

Genc, H. and Tjell, J. C., 2003, Effects of phosphate, silicate, sulphate, and bicarbonate on arsenate removal using activated seawater neutralized red mud (bauxsol). J. Phys. IV France, v. 107, pp. 537-540.

Guillot, S., Pecher, A., and Le Fort, P., 1994, Comparison of the emplacement of some High-Himalayan leucogranites (Mugu-Mustang, Manaslu and Kula-Kangri). J. Nepal Geol. Soc., v. 10, p. 61.

Gurung, J. K., Ishiga, H., and Khadka, M. S., 2005, Geological and geochemical examination of arsenic contamination in groundwater in the Holocene Terai Basin, Nepal. Environ. Geol., v. 49, pp. 98-113.

Gurung, J. K., Ishiga, H., Khadka, M. S., and Shrestha, N. R., 2006, Comparison of arsenic and nitrate contaminations in shallow and deep aquifers of Kathmandu valley. J. Nepal Geol. Soc., v. 33, pp. 55-62.

Hach Company, 2013, Arsenic, Silver Diethyldithiocarbamate Method, Method 8013, DOC316.53.01005, www.hach. com.

Harvey, C. F., Swartz, C. H., Badruzzaman, A. B. M., KeonBlute, N., Yu, W., Ali, M. A., Jay, J., Beckie, R., Niedan,
V., Brabander, D., Oates, P. M., Ashfaque, K. N., Islam, S., Hemond, H. and Ahmed, M. F., 2002, Arsenic mobility and groundwater extraction in Bangladesh. Science, v. 298, pp. 1602-1606.

Hearn, P., Hare, T., Schruben, P., Sherrill, D., LaMar, C., and Tsushima, P., 2001, Global GIS Database: Digital Atlas of South Asia, U.S. Geological Survey Digital Data Series DDS-62-C.

Hurtado, J. M., Hodges, K. V., and Whipple, K. X., 2001, Neotectonics of the Thakkhola graben and implications for recent activity on the South Tibetan fault system in the central Nepal Himalaya. Geol. Soc. Amer. Bull., v. 113, pp. 222-240.

Hurtado, J. M., Hodges, K. V., Ramezani, J., and Bowring, S. A., 2002, Exhumation of the upper Mustang Massif, Thakkhola Graben, central Nepal Himalaya. Abstracts with Programs - Geol. Soc. Amer., v. 34, pp. 107-108.

Kanel, S. R., Choi, H., Kim, K. W., and Moon, S.H., 2005, Arsenic contamination in groundwater in Nepal: A new perspective and more health threat in South Asia, In: Bundschuh, J., Bhattacharya, P., and Chandrasekharam, D., (Eds.) Natural Arsenic in Groundwater: Occurrence, Remediation and Management, A. A. Balkema Publishers, Leiden, pp. 103-108.

Keon, N. E., Swartz, C. H., Brabander, D. J., Harvey, C. and Hemond, H. F., 2001, Validation of an arsenic sequential extraction method for evaluating mobility in sediments. Environ. Sci. Technol., v. 35, pp. 2778-2784.

Khatiwada, N. R., Takizawa, S., Tran, T. V. N., and Inoue, M., 2002, Groundwater contamination assessment for sustainable water supply in Kathmandu Valley, Nepal. Water Sci. Technol., v. 46, pp. 147-154.

Koirala, A. and Rimal, L. N., 1996, Geological hazards in Pokhara Valley, western Nepal. J. Nepal Geol. Soc., v. 14, pp. 99-108.

Koirala, A. Hanisch, J., and Geyh, M. A., 1997, Recurrence history of debris flow events in Pokhara Valley; a preview. J. Nepal Geol. Soc., v. 16, pp. 93-94.

Koirala, A., Rimal, L. N., Sikrikar, S. M., Pradhananga, U. B., and Pradhan, P. M., 1998, Engineering and Environmental Geological Map of Pokhara Valley, Scale 1:50 000, Department of Mines and Geology, Kathmandu, Nepal.

Kopp, J. F., 1973, 1-Ephedrine in chloroform as a solvent for silver diethyldithiocarbamate in the determination of arsenic. Anal. Chem., v. 45, pp. 1786-1787.

Langmuir, D., 1997, Aqueous Environmental Chemistry, Prentice-Hall, Upper Saddle River, New Jersey, 600 p.

Le Fort, P. and France-Lanord, C., 1994, Granites from Mustang and surrounding regions, central Nepal. J. Nepal Geol. Soc., v. 10, pp. 79-80.

Le Fort, P. and France-Lanord, C., 1995, Granites from Mustang and surrounding regions (central Nepal). J. Nepal Geol. Soc., v. 11, pp. 53-57.

Maharjan, M., Watanabe, C., Akhtar Ahmad, Sk. and Ohtsuka, R., 2005, Arsenic contamination in drinking water and skin manifestations in lowland Nepal: The first community-based survey. Am. J. Trop. Med. Hyg., v. 73, 
pp. 477-479.

Maharjan, M., Shrestha, R. R., Akhtar Ahmad, Sk., Watanabe, C., and Ohtsuka, R., 2006, Prevalence of arsenicosis in Terai, Nepal. J. Health, Popul. Nutr., v. 24, pp. 246-252.

Maharjan, M., Watanabe, C., Akhtar Ahmad, Sk. and Ohtsuka, R., 2007, Mutual interaction between nutritional status and chronic arsenic toxicity due to groundwater contamination in an area of Terai, lowland Nepal. J. Epidemiol. Community Health, v. 61, pp. 389-394.

Maharjan, M., Shrestha, B. R., Shrestha, K. B., Shrestha, R. R., Raut (Khadka), R., Kafle, B., and Ishihara, H., 2009, Arsenic contamination in groundwater resources in Kathmandu Valley, In: Takizawa, S., Kurisu, F., and Satoh, H., (Eds.) Southeast Asian Water Environment, v. 3, IWA Publishing, London, pp. 73-79.

Mallick, S. and Rajgopal, N. R., 1996, Groundwater development in the arsenic-affected alluvial belt of West Bengal - some questions. Current Sci., v. 70, pp. 956958.

Manna, B. R., Dey, S., Debnath, S., and Ghosh, U. C., 2003, Removal of arsenic from groundwater using crystalline hydrous ferric oxide (CHFO). Water Qual. Res. J. Can., v. 38 , pp. $193-210$.

Marshall, N. J., 1978, Colorimetric determination of arsenic in geochemical samples. J. Geochem. Explor., v. 10, pp. 307-313.

McArthur, J. M., Ravenscroft, P., Safiullah, S. and Thirlwall, M. F., 2001, Arsenic in groundwater: Testing pollution mechanisms for sedimentary aquifers in Bangladesh. Water Resour. Res., v. 37, pp. 109-117.

National Geographic, 2013, National Geographic World Map, http://goto.arcgisonline.com/maps/NatGeo_World_Map.

Neku, A. and Tandukar, N., 2002, A report on arsenic programme (Mitigation measures and a training manual). Department of Water Supply and Sewerage, Ministry of Physical Planning and Works, Kathmandu, Nepal, 53 p.

Neku, A., Brikowski, T. H., Suenaga, K., Yokoto, H., Kshattry, I., and Ammann, L., 2006, Hydrogeology of a groundwater arsenic hotspot, Thulokunuwar Village, Nawalparasi, Nepal. Abstracts with Programs - Geol. Soc. Amer., South-Central Sec., v. 38, p. 7.

Neku, A. and Brikowski, T., 2009, Temporal variability of groundwater hydrochemistry in aquifers of Nawalparasi, Nepal. Abstracts with Programs - Geol. Soc. Amer., v. 41, pp. 32-33.

Nepal Map Publisher, n.d., Trekking Map, Upper \& Lower Mustang, 1:70,000, Nepal Map Publisher Pvt. Ltd., Kathmandu, Nepal.

Nickson, R. T., McArthur, J. M., Burgess, W. G., Ahmed, K. M., Ravenscroft, P., and Rahman, M., 1998, Arsenic poisoning of Bangladesh groundwater. Nature, v. 395, p. 338.

Nickson, R. T., McArthur, J. M., Ravenscroft, P., Burgess, W. G. and Ahmed, K. M., 2000, Mechanism of arsenic release to groundwater, Bangladesh and West Bengal. Appl. Geochem., v. 15, pp. 403-413.

Panthi, S. R., Sharma, S., and Mishra, A. K., 2006, Recent status of arsenic contamination in groundwater of Nepal - A review. Kathmandu Univ. J. Sci. Technol., v. 2, pp. $1-11$.

Paudel, K. P., 2010, Assessing rangeland degradation using multi-temporal satellite images and grazing pressure surface model in Upper Mustang; Trans Himalaya, Nepal. Remote Sens. Environ., v. 114, pp. 1845-1855.

Pokhrel, D., Bhandari, B. S., and Viraraghavan, T., 2009, Arsenic contamination of groundwater in the Terai region of Nepal: An overview of health concerns and treatment options. Environ. Int., v. 35, pp. 157-161.

Polizzotto, M. L., Harvey, C. F., Li, G., Badruzzman, B., Ali, A., Newville, M., Sutton, S., and Fendorf, S., 2006, Soil-phases and desorption processes of arsenic within Bangladesh sediments. Chem. Geol., v. 228, pp. 97-111.

Rice, E. W., Baird, R. B., Eaton, A. D., and Clesceri, L. S. (Eds.), 2012, Standard Methods for the Examination of Water and Wastewater, 22nd ed., American Public Health Association, Washington, D.C., 1496 p.

Saar, R. A., 1997, Filtration of ground water samples: A review of industry practice. Ground. Water Monit. R., Winter 1997, pp. 56-62.

Saijo, K. and Satoshi, T., 2002, Paleosols of middle Holocene age in the Thakkhola Basin, central Nepal, and their paleoclimatic significance. J. Asian Earth Sci., v. 21, pp. 323-329.

Salbu, B., Pappas, A. C., and Steinnes, A. C., 1979, Elemental composition of Norwegian rivers. Nord. Hydrol., v. 10, pp. 115-140.

Sanders, L., 1998, A Manual of Field Hydrogeology, PrenticeHall, Upper Saddle River, New Jersey, 381 p.

Shrestha, R. R., Shrestha, M. P., Upadhyay, N. P., Pradhan, R., Khadka, R., and Maskey, A., 2003, Groundwater arsenic contamination, its health impact and mitigation program in Nepal. J. Environ. Sci. Health, v. A38, pp. 185-200.

Shrestha, S. D., Brikowski, T., Smith, L., and Shei, T.-C., 2004, Grain size constraints on arsenic concentration in shallow wells of Nawalparasi, Nepal. J. Nepal Geol. Soc., v. 30, pp. 93-98.

Smedley, P. L. and Kinniburgh, D. G., 2002, A review of the source, behavior and distribution of arsenic in surface waters. Appl. Geochem., v. 17, pp. 517-568.

Tandukar, N., Bhattacharya, P., Jacks, G., and Valero, A. A., 2005, Naturally occurring arsenic in groundwater of Terai region in Nepal and mitigation options, In: Bundschuh, J., Bhattacharya, P., and Chandrasekharam, D., (Eds.) Natural Arsenic in Groundwater: Occurrence, Remediation and Management, A. A. Balkema Publishers, Leiden, pp. 41-48.

Thakur, J. K., Thakur, R. K., Ramanathan, A. L., Kumar, M., and Singh, S. K., 2011, Arsenic contamination of groundwater in Nepal-An overview. Water, v. 3, pp. 1-20, doi:10.3390/w3010001.

Upreti, B. N. and Yoshida, M. (Eds.), 2005, Guidebook for Himalayan Trekkers, Series No.1: Geology and Natural Hazards along the Kaligandaki Valley, Nepal, Department of Geology, Tri-Chandra Campus, Tribhuvan University, 
Kathmandu, Nepal, 165p.

Van Geen, A., Radloff, K., Aziz, Z., Cheng, Z., Huq, M. R., Ahmed, K. M., Weinman, B., Goodbred, S., Jung, H. B., Zheng, Y., Berg, M., Trang, P. T. K., Charlet, L., Metral, J., Tisserand, D., Guillot, S., Chakraborty, S., Gajurel, A. P., and Upreti, B. N., 2008, Comparison of arsenic concentrations in simultaneously-collected groundwater and aquifer particles from Bangladesh, India, Vietnam, and Nepal. Appl. Geochem., v. 23, pp. 3244-3251.

Warner, N. R., Levy, J., Harpp, K., and Farruggia, F., 2008, Drinking water quality in Nepal's Kathmandu Valley: A survey and assessment of selected controlling site characteristics. Hydrogeol. Jour., v. 16, pp. 321-334.

WCD (Wildlife Conservation Division), 2010, Analysis of the Contributions of Protected Areas to the Social and Economic Development of Bhutan - A Case Study of Jigme Singye Wangchuck National Park. Wildlife Conservation Division, Ministry of Agriculture and Forests, Thimphu, Bhutan.

WHO (World Health Organization), 2008, Guidelines for Drinking-water Quality, Third Edition, Incorporating the First and Second Addenda, Vol.1: Recommendations, WHO, Geneva, $515 \mathrm{p}$.

Williams, V. S., Breit, G. N., Whitney, J., and Yount, J. C., 2004, Investigations on the relation of arsenic-bearing sediments to arsenic contaminated groundwater beneath the plains of Nepal. Abstracts with Programs - Geol. Soc. Amer., v. 36, pp. 558-559.

Williams, V. S., Kansakar, D. R., and Ghimire, B., 2005, Nepalese groundwater arsenic contamination is related to Siwalik source rock. Abstracts with Programs - Geol. Soc. Amer., v. 37, 170 p. 